\title{
Crops that feed the world 10. Past successes and future challenges to the role played by wheat in global food security
}

\author{
Bekele Shiferaw • Melinda Smale • Hans-Joachim Braun • \\ Etienne Duveiller • Mathew Reynolds • Geoffrey Muricho
}

Received: 24 July 2012 / Accepted: 2 April 2013 / Published online: 28 April 2013

(C) The Author(s) 2013. This article is published with open access at Springerlink.com

\begin{abstract}
Wheat is fundamental to human civilization and has played an outstanding role in feeding a hungry world and improving global food security. The crop contributes about $20 \%$ of the total dietary calories and proteins worldwide. Food demand in the developing regions is growing by $1 \%$ annually and varies from $170 \mathrm{~kg}$ in Central Asia to $27 \mathrm{~kg}$ in East and South Africa. The developing regions (including China and Central Asia) account for roughly $53 \%$ of the total harvested area and $50 \%$ of the production. Unprecedented productivity growth from the Green Revolution (GR) since the 1960s dramatically transformed world wheat production, benefitting both producers and consumers through low production costs and low food prices. Modern wheat varieties were adopted more rapidly than any other technological innovation in the history of agriculture, recently reaching about $90 \%$ of the area in developing regions. One of the key challenges today is to replace these varieties with new ones for better sustainability. While the GR "spared" essential ecosystems from conversion to agriculture, it also generated its own environmental problems. Also productivity increase is now slow or static. Achieving the productivity gains needed to ensure food security will therefore require more than a repeat performance of the GR of the past. Future demand will need to be achieved through sustainable intensification that combines better crop resistance to diseases and pests, adaptation to warmer climates, and reduced use of water, fertilizer, labor
\end{abstract}

B. Shiferaw $(\bowtie) \cdot$ G. Muricho

Socioeconomics Program, CIMMYT-International Maize and

Wheat Improvement Center, Nairobi, Kenya

e-mail: b.shiferaw@cgiar.org

M. Smale

Department of Agricultural, Food and Resource Economics,

Michigan State University, East Lancing, USA

H.-J. Braun • E. Duveiller • M. Reynolds

Global Wheat Program, CIMMYT-International Maize and Wheat

Improvement Center, El Batán, Mexico and fuel. Meeting these challenges will require concerted efforts in research and innovation to develop and deploy viable solutions. Substantive investment will be required to realize sustainable productivity growth through better technologies and policy and institutional innovations that facilitate farmer adoption and adaptation. The enduring lessons from the GR and the recent efforts for sustainable intensification of cereal systems in South Asia and other regions provide useful insights for the future.

Keywords Food security · Demand · Supply · Utilization · Technology adoption $\cdot$ Produtivity growth $\cdot$ Climate change . Wheat

\section{Introduction}

Wheat is a crop that is fundamental to human civilization. Between 8 and 10 thousand years ago, in the earliest permanent agricultural settlements of the Fertile Crescent, farmers developed bread wheat from emmer and einkorn grasses (Smith 1998). It is now the most widely cultivated cereal in the world with more than 220 million ha planted annually under wide ranges of climatic conditions and in many geographic regions. Depending on agro-climatic conditions, about 670 million tons are produced annually. Consequently, wheat is one of the most important crops for global food security. Wheat production is split roughly equally between the developing and developed world, although production methods may differ. The developing regions (including China and Central Asia) account for roughly $53 \%$ of the total harvested area and $50 \%$ of the production. Yields are about $14 \%$ higher in the developed world mainly because rainfed yields are very low in Central Asia. If one excludes Central Asia, yields in the two regions are similar (around $3 \mathrm{t} / \mathrm{ha}$ ) mainly because nearly all wheat produced in developing countries is irrigated while wheat produced in developed 
countries is mostly rain-fed (Table 1). The unprecedented growth in the productivity of wheat achieved through the Green Revolution in many developing regions (e.g. South Asia, South East Asia, West Asia, North Africa and Latin America) has helped overcome famines and has saved millions of lives. Because of this, wheat is often described as the 'miracle crop' of the last century. The dramatic growth in productivity was made possible through technological achievements in developing the semi-dwarf, high yielding varieties and favorable policy and institutional support in ensuring farmer access to new seeds, fertilizer, markets and irrigation infrastructure. This has made significant contributions in reducing hunger and poverty (Datt and Ravallion 1998; Fan and Hazell 2001; Evenson and Rosegrant 2003; Renkow and Byerlee 2010).

Wheat, together with rice, are premier products of publicly funded, international plant breeding research. Without what is now referred to as the Green Revolution in the agriculture of developing countries, it is generally acknowledged that there would be large food deficits today. The principal manifestation of the Green Revolution was the development and diffusion of short-strawed, fertilizerresponsive varieties of wheat and rice in the 1960s and 1970 s, generally bolstered by subsidized delivery of inputs, guaranteed and higher wheat prices for farmers, and associated public investments in irrigation, land reform and infrastructure. Initially targeted to the irrigated areas in Asia, public investments in wheat research led to "a quantum leap in crop yields, but neglected rain-fed and marginal lands" (Pal and Byerlee 2005: 177), though high-yielding varieties diffused gradually across many rain-fed environments in South Asia and elsewhere, including Turkey, Iran, Argentina, Brazil, and South Africa.

Early improved varieties spread rapidly over high potential production areas, which led to widespread adoption in South Asia, especially in irrigated areas, followed by rainfed areas of Latin America, West Asia and North Africa. This boosted average yields during $1966-79$ by $3.6 \%$ per annum in developing countries. This level of productivity growth, however, was not sustained; it slipped to $2.8 \%$ per annum during 1984-94 and dropped to $1.1 \%$ during $1995-$ 2005 (Dixon et al. 2009). By the 1990s, evidence was

Table 1 Average annual wheat area, production, yield and recent growth rates

\begin{tabular}{|c|c|c|c|c|c|c|}
\hline \multirow[t]{3}{*}{ Region } & \multirow{2}{*}{\multicolumn{3}{|c|}{$\begin{array}{l}\text { Average area, production and yields } \\
(2008-2010)\end{array}$}} & \multicolumn{3}{|c|}{ Average annual growth rates } \\
\hline & & & & \multicolumn{3}{|l|}{ 2001-2010 } \\
\hline & $\begin{array}{l}\text { Area } \\
\text { (million ha) }\end{array}$ & $\begin{array}{l}\text { Production } \\
\text { (million tons) }\end{array}$ & $\begin{array}{l}\text { Yield } \\
\text { (tons/ha) }\end{array}$ & $\begin{array}{l}\text { Area growth } \\
\text { rate }(\%)\end{array}$ & $\begin{array}{l}\text { Production } \\
\text { growth rate }(\%)\end{array}$ & $\begin{array}{l}\text { Yield growth } \\
\text { rate }(\%)\end{array}$ \\
\hline E\&S Africa with RSA & 2.83 & 5.92 & 2.09 & 1.82 & 3.35 & 1.55 \\
\hline E\&S Africa without RSA & 2.18 & 4.08 & 1.87 & 4.76 & 8.87 & 4.08 \\
\hline Western \& Central Africa & 0.06 & 0.10 & 1.64 & 1.01 & 1.11 & 1.86 \\
\hline North Africa & 6.48 & 16.52 & 2.54 & 2.50 & 8.01 & 4.59 \\
\hline West Asia & 20.05 & 42.34 & 2.10 & 0.66 & 3.72 & 2.72 \\
\hline South Asia & 38.19 & 105.32 & 2.76 & 0.38 & 0.74 & 0.30 \\
\hline Southeast Asia \& Pacific & 0.00 & 0.00 & 1.02 & -0.83 & 3.30 & 4.61 \\
\hline East Asia & 24.35 & 114.76 & 4.71 & -0.80 & 1.61 & 2.48 \\
\hline $\begin{array}{l}\text { Mexico, Central America \& } \\
\text { Caribbean (CAC) }\end{array}$ & 0.78 & 3.95 & 5.10 & 0.30 & 1.40 & 1.13 \\
\hline Andean Region, South America & 0.34 & 0.47 & 1.38 & 1.41 & 4.04 & 3.03 \\
\hline Southern Cone, South America & 7.57 & 20.40 & 2.69 & -0.11 & 4.31 & 4.03 \\
\hline Eastern Europe \& Russia & 42.13 & 116.94 & 2.76 & 1.31 & 6.91 & 3.42 \\
\hline Central Asia & 17.29 & 25.94 & 1.50 & 2.33 & 4.11 & 1.39 \\
\hline North America (USA \& Canada) & 29.98 & 89.02 & 2.97 & -1.25 & 1.13 & 1.65 \\
\hline Australia $^{\mathbf{a}}$ & 13.61 & 21.74 & 1.60 & 1.73 & 0.73 & -0.98 \\
\hline $\begin{array}{l}\text { Western Europe \& other High } \\
\text { Income Countries }\end{array}$ & 17.87 & 111.07 & 6.22 & -0.03 & 0.91 & 0.67 \\
\hline Developing countries & 117.94 & 335.72 & 2.85 & 0.37 & 1.72 & 1.33 \\
\hline Developed countries & 103.59 & 338.77 & 3.27 & -0.10 & 1.34 & 1.09 \\
\hline World & 221.53 & 674.49 & 3.04 & 0.12 & 1.27 & 1.09 \\
\hline
\end{tabular}

FAOSTAT online database, 30 Dec. 2012

${ }^{\text {a }}$ Growth rates computed using the OLS regression method. The average annual growth rates were dropped mainly due to large growth in 2003 (17\% in area, $120 \%$ in yield and $158 \%$ in production) which affected the average annual growth rates 
accumulating in Asia that the impacts of technical change were uneven across different agroecological areas and that the poor outside irrigated areas had not benefited fully from the increases in productivity. A "farming systems" movement was, in part, a response to recognition that farmers in diverse, risk-prone areas could not take advantage of standardized packages of practices (Tripp 2006). Meanwhile, better off farmers in the irrigated areas were beset by stagnating yields and environmental problems (Byerlee and Siddiq 1994; Ali and Byerlee 2001), such as salinity and waterlogging. These have been of concern for food security in many developing regions where wheat is the major staple crop. Even more disconcerting are the implications of climate change for wheat throughout the developing world. Lobell et al. (2011) showed that rising temperatures since 1980 have already lowered wheat yields by $5.5 \%$. No other major staple crop is expected to suffer production losses as severe as those projected for wheat owing to rising temperatures, particularly night time temperatures in low-latitude countries (Ortiz et al. 2008; Lobell et al. 2011). Climate change induced temperature increases are estimated to reduce wheat yields in irrigated systems by 5.3 to $7.4 \%$ in developing countries and by $0.1 \%$ in the developed countries (Nelson et al. 2010). Extreme day-time temperatures at anthesis in high latitudes are predicted to represent particular threats to wheat yields (Semenov and Shewry 2011).

Wheat production will also suffer from the effects of falling irrigation water supplies, declining soil fertility, and threats from emerging diseases. Wheat farming systems, particularly those in South and West Asia and North Africa, are projected to suffer most from heat stress and water scarcity due to climate change. With increasing drought incidence and water scarcity, wheat is likely to be grown increasingly under rainfed conditions, since among the major staple crops it is the most drought tolerant and water use efficient (Ortiz et al. 2008). This will escalate the risks faced by farmers and expose consumers to extreme price fluctuations. At the same time, farmers can expect sharp increases in the price of fertilizers, driven by rising costs for fossil fuels and depleting reserves of phosphorus and potassium (Cordell et al. 2010).

Slowing productivity growth, caused by biotic and abiotic stresses, is further complicated by changing consumption patterns and the growing demand for wheat. Demand for wheat in the developing world is projected to increase and quality-differentiated demand for wheat products will place new demands on market channels; greater economic integration will also shift the directions and volumes of trade. Demand for wheat has been increasing in many countries including those of the African continent and is projected to grow by $2.6 \%$ per annum until 2020 . The demand in the developing world is projected to increase $60 \%$ by 2050 (Nelson et al. 2010). Except in a few developing countries, the demand for wheat is being met increasingly through imports; wheat now accounts for the largest food import (43\%) to developing countries (Dixon et al. 2009).

Future food security in densely populated countries with fast growing populations and countries that rely on imports of wheat therefore depend on reversing stagnating productivity and addressing the threats from climate change. Achieving the productivity increases needed to ensure regional and global food security will therefore require more than a repeat performance of the Green Revolution, because conditions have changed since the 1960s. Short term productivity growth alone will neither provide the solution to the challenges of climate change nor ensure long term food security for growing populations. A different type of Green Revolution which is based on the principles of sustainable intensification of agro-ecosystems is now called for in order to reverse productivity decline, increase resilience against climate change and bring benefits to areas that did not gain much from productivity growth in the past. The spread of new varieties particularly needs to go hand in hand with sustainable management practices to prevent the worsening water scarcity and soil degradation: these prevent farmers from realizing the benefits of new technologies and create disincentives for their adoption. Greater investment in research, institutional innovation, functioning markets and policies for replacement of outdated cultivars with modern ones will be required (Byerlee and Traxler 1995). In addition, stimulation of farmer investment in sustainable crop, soil and water management practices will be needed.

This article aims to increase awareness of the importance of wheat for global food security and of the current and future challenges to be addressed if the production required to meet the increasing demand for feeding growing populations is to be achieved sustainably. It is hoped that such information will contribute to current debates and appropriate choices of policies and actions required to enhance current and future food security in wheat as a major food staple. The paper is organized as follows: in Section "Role of wheat for global food security" we analyse the role of wheat for food, nutrition and livelihood security by examining the importance of wheat in the growing demand for food at the regional and global levels. Section "Historical patterns in wheat production and productivity" highlights the historical patterns of productivity change in wheat and future trends. Section "Constraints to productivity growth" looks at the constraints to productivity growth in terms of biotic and abiotic stress and the challenges for breeding better varieties. The vulnerability of wheat to climate change and its potential impact is addressed in Section "Vulnerability to climate change". Section "Future technology options" presents the future technical options for overcoming biotic and abiotic constraints to production. Section "Technology targeting and adoption" outlines the current knowledge on adoption of wheat technologies and constraints 
in delivering better varieties, inputs and services to farmers. We conclude in Section "Conclusions" by highlighting the key lessons and action points for policy-makers, researchers and development practitioners.

\section{Role of wheat for global food security}

As in the Fertile Crescent $8-10,000$ years ago, wheat is a mainstay of today's human diet. It contributes about onefifth of daily calories and protein, which is substantially more than maize (Table 2, last two columns). Maize contributes about $5 \%$ of the dietary calories and $4 \%$ of the proteins, while rice contributes about $19 \%$ of the calories and $13 \%$ of the proteins at the global level (not shown). In developing countries, wheat provides about $18 \%$ of daily caloric needs, as compared to $19 \%$ globally and $21 \%$ in high income countries. ${ }^{1}$ Wheat is also the world's most important protein source and provides on average about $21 \%$ of the daily dietary protein intake. When one looks at the contributions from total cereal consumption, wheat accounts for about $41 \%$ of the calories and $50 \%$ of the proteins. These shares increase to about $75 \%$ and $81 \%$ for cereal-based calories and proteins, respectively, in the developed regions while it accounts for $35 \%$ and $44 \%$ for the developing regions (Fig. 1 and Table 2, column 2 and 3). The highest annual per capita food demand for wheat is in Central Asia (171 kg) followed by North Africa (165 kg), West Asia (122 kg), and Eastern Europe and Russia $(120 \mathrm{~kg})$. In Central Asia, wheat provides about $47 \%$ of the daily calories and proteins while it contributes $40-43 \%$ of the same requirements in North Africa and West Asia. Wheat also remains a major source of dietary calories and proteins in Eastern Europe and Russia (28-29\%), and South Asia (20-24\%) and high income countries (20\%). In countries where wheat is among the top three food crops, wheat is an especially critical component of the diet for the approximately 2.5 billion poor people who live on less than US\$2/day, (of whom most are women and children). The highest level of dependence on wheat as the main source of cereal calories and proteins is found in Central Asia (89 and $91 \%$ ), Eastern Europe and Russia (81 and $84 \%$ ), Australia (78 and $85 \%$ ), West Asia (78 and $84 \%$ ), North America (73 and $80 \%$ ), North Africa (66 and $71 \%$ ) and other high income countries (70 and $79 \%$ ). In these regions, wheat accounts for over three-quarters of cereal intake.

The available data indicates that the growth rate in per capita food demand globally declined from $1.28 \%$ during the 1970 s to $0.49 \%$ during the 1980 s, $0.04 \%$ during the 1990 s and $-0.38 \%$ during the 2000 s. Per capita wheat

\footnotetext{
${ }^{1}$ Unless otherwise indicated, Central Asia and China are included under the developing countries.
}

consumption growth rates (for food as distinct from animal feed) particularly declined in higher income countries, growth rates becoming negative during one or both of the last two decades in: Australia, North America, Eastern Europe and former Soviet Union, the Southern Cone of Latin America, Mexico and Central America, West Asia, and East Asia. However, growth rates seem to be increasing again in the Andean region, Southern Cone of Latin America, Western Europe and Australia (Table 3). Compared to the high growth rates in the 1970s, wheat per capita demand growth rates for food seem to have declined globally at the level $0.38 \%$ per year during the past 10 years. This indicates that consumers are diversifying consumption as income and urbanization grows, especially in developing regions. ${ }^{2}$ Despite the slowing per capita growth rates, it should be noted that per capita demand for wheat as food has doubled in the developing regions from about $30 \mathrm{~kg}$ in the 1960 s to about $60 \mathrm{~kg}$ during the last decade. Globally, per capita demand has grown from $54 \mathrm{~kg}$ to about $64 \mathrm{~kg}$ during the past half century. The declining global per capita demand also hides the significant growth in total demand for food especially in the developing regions driven by population, income growth and changes in dietary preferences. The demand for food in the developing regions (not shown) increased annually by $5-6 \%$ in the 1960 s and $1970,3 \%$ in the $1980 \mathrm{~s}, 2.5 \%$ in the $1990 \mathrm{~s}$ and $1 \%$ in the last decade. As a result, food demand for wheat in the developing regions has increased by more than five-fold since 1960, i.e., 60 million tons in 1960 to 321 million tons in 2009. The total food demand has not, however, grown significantly in the developed countries during the recent decades (average growth was about $0.25 \%$ during 2001-2009). At the global level, food demand has grown by about $0.82 \%$ annually during the recent decade. It is also important to note the growing per capita demand for wheat in Sub-Saharan Africa and Central Asia. In the sub-Saharan African regions, wheat demand has grown by 2 to $3 \%$ per year during 1961-2009 mainly fuelled by growing urbanization and income growth. This has prompted many sub-Saharan countries to increase wheat imports, which reached some 15 million tons by 2012 .

In addition, the total global demand for wheat has almost quadrupled since the 1960s and doubled over the four decades since 1980 to 635 million tons in 2009. About twothird of the demand for wheat comes from the developing regions. Since the 1970s, the total demand in the developing regions has more than tripled to about 390 million tons. This compares with the more than tripling of global demand for

\footnotetext{
${ }^{2}$ As a reflection of urbanization, and in some cases, preferences for wheat with rising incomes, growth rates in per capita wheat consumption increased from 1996 to 2005 relative to the period from 1980 to 1995 especially in Africa, Eastern Europe and the former Soviet Union, and to a minor extent in Southeast Asia and the Pacific, Mexico, Central America and the Caribbean (Aquino and Carrión 2009).
} 
Table 2 Average wheat consumption and its share in calorie and protein intake (2005-2009)

\begin{tabular}{|c|c|c|c|c|c|}
\hline \multirow[t]{2}{*}{ Region } & \multirow{2}{*}{$\begin{array}{l}\text { Food demand per } \\
\text { capita (kg/year) }\end{array}$} & \multicolumn{2}{|c|}{ Share in cereal intake $(\%)$} & \multicolumn{2}{|c|}{ Share in total dietary intake $(\%)$} \\
\hline & & Calories & Protein & Calories & Protein \\
\hline E\&S Africa with RSA & 27.93 & 21.66 & 24.79 & 10.44 & 11.63 \\
\hline E\&S Africa without RSA & 23.35 & 19.41 & 22.02 & 9.20 & 10.14 \\
\hline Western \& Central Africa & 16.31 & 12.33 & 13.78 & 5.58 & 6.61 \\
\hline North Africa & 165.12 & 66.37 & 71.12 & 39.70 & 42.51 \\
\hline West Asia & 121.51 & 78.94 & 84.21 & 39.44 & 43.95 \\
\hline South Asia & 56.97 & 34.67 & 42.58 & 20.51 & 23.99 \\
\hline Southeast Asia \& Pacific & 19.78 & 9.79 & 13.35 & 5.77 & 6.69 \\
\hline East Asia & 65.89 & 40.07 & 53.48 & 19.53 & 20.74 \\
\hline Mexico and CAC & 34.65 & 21.31 & 23.12 & 9.07 & 9.09 \\
\hline Andean Region, South America & 42.60 & 31.41 & 38.37 & 11.92 & 13. 30 \\
\hline Southern Cone, South America & 64.94 & 49.08 & 54.45 & 15.56 & 14.63 \\
\hline Eastern Europe \& Russia & 120.10 & 81.64 & 84.31 & 28.66 & 29.47 \\
\hline Central Asia & 171.53 & 89.49 & 91.71 & 46.96 & 46.71 \\
\hline North America (USA \& Canada) & 83.90 & 73.42 & 80.80 & 16.49 & 17.40 \\
\hline Australia & 70.05 & 78.22 & 85.62 & 17.49 & 19.47 \\
\hline Western Europe \& other high income countries & 86.78 & 69.76 & 79.07 & 19.95 & 20.02 \\
\hline Developing countries & 57.87 & 35.82 & 44.66 & 18.38 & 20.46 \\
\hline Developed countries & 94.53 & 74.45 & 81.27 & 21.08 & 21.53 \\
\hline World & 64.71 & 41.29 & 50.65 & 19.01 & 20.77 \\
\hline
\end{tabular}

Computed by authors based on FAOSTAT online database, 30 Dec. 2012

maize to 770 million tons and the more than quadrupling in the developing regions to 430 million tons during the same period (Shiferaw et al. 2011). The total global annual demand for wheat has grown at an average rate of about $2.24 \%$ per year since 1960 s but slowed to about $1 \%$ in the last decade (Table 4). During the recent decades, total demand (all uses) has grown annually by about $1.4 \%$ in the developing regions and $0.7 \%$ in the developed regions. The total demand seems to be growing fast in new regions including Eastern and Southern Africa (5.8 \%), West and Central Africa (4.7\%) and South Asia and Pacific (4.3\%). From the traditional wheat growing regions, demand growth rates are highest in Central Asia (5.6\%), Australia (2.6\%) and North Africa (2.2\%).
Fig. 1 Average annual calorie and protein intake share of cereal (\%), 2005-2009. Source: Computed by authors based on FAOSTAT online database, 30 Dec. 2012

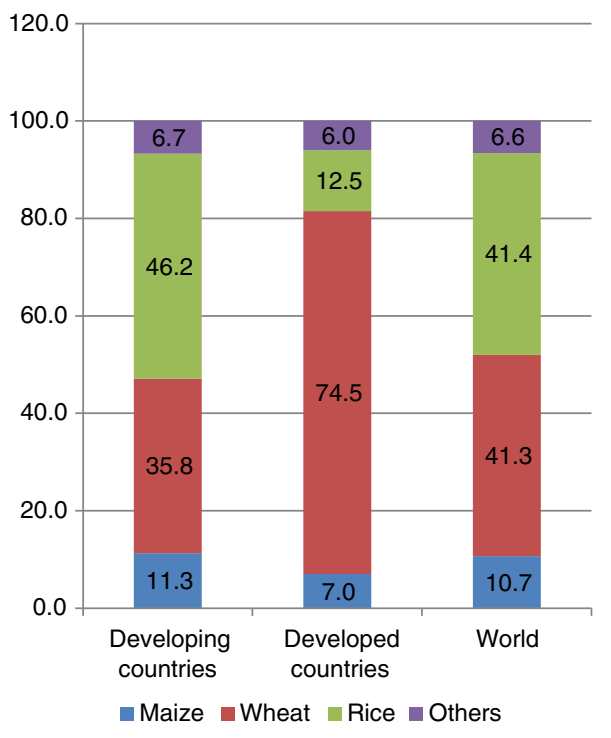

Panel A: Cereal calorie shares (\%)

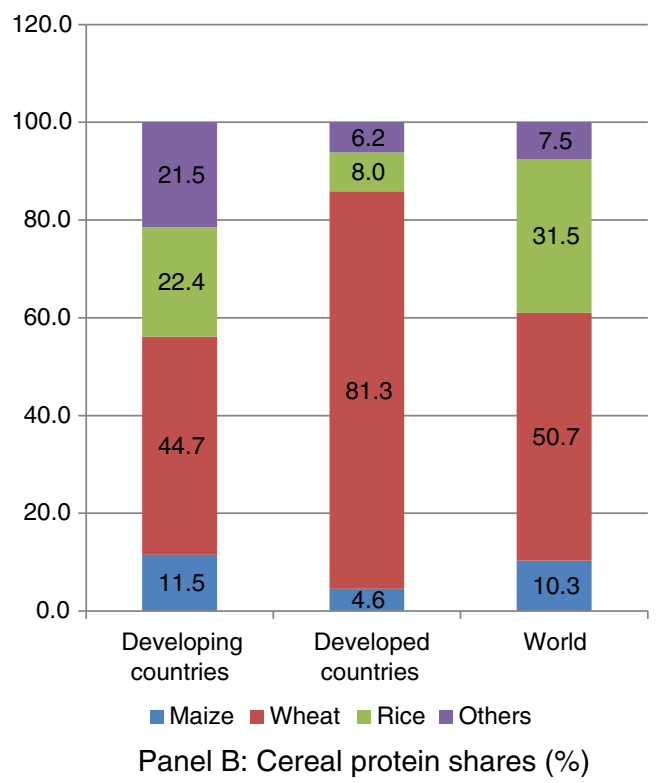


Table 3 Average annual percent growth rate of wheat consumption per capita as food (1961-2009)

\begin{tabular}{|c|c|c|c|c|c|c|}
\hline Region & $1961-1970$ & 1971-1980 & $1981-1990$ & $1991-2000$ & $2000-2009$ & 1961-2009 \\
\hline E\&S Africa with RSA & 2.45 & 0.69 & 0.62 & 1.29 & 1.63 & 1.31 \\
\hline E\&S Africa without RSA & 3.65 & 0.90 & 0.84 & 1.76 & 2.64 & 1.91 \\
\hline Western and Central Africa & 6.81 & 8.45 & -3.27 & 6.97 & 2.02 & 4.19 \\
\hline North Africa & 1.11 & 3.60 & 0.62 & -0.57 & 0.50 & 1.06 \\
\hline West Asia & 1.43 & 1.62 & 1.08 & -0.75 & -0.86 & 0.51 \\
\hline South Asia & 3.42 & 2.51 & 0.01 & 2.79 & 0.21 & 1.79 \\
\hline Southeast Asia and Pacific & 9.08 & 3.49 & -1.15 & 6.50 & 2.54 & 4.02 \\
\hline East Asia & 5.67 & 5.95 & 2.88 & -0.54 & -1.19 & 2.57 \\
\hline Mexico and CAC & 2.57 & 1.94 & -0.15 & -0.68 & -1.03 & 0.52 \\
\hline Andean Region, South America & -0.58 & 2.23 & -0.10 & 1.33 & 0.49 & 0.71 \\
\hline Southern Cone, South America & 0.62 & 1.46 & -0.92 & -0.06 & 0.63 & 0.34 \\
\hline Eastern Europe \& Russia & -0.80 & -0.83 & 0.22 & -1.73 & -0.16 & -0.67 \\
\hline Central Asia & & & & -0.49 & 1.01 & 0.30 \\
\hline North America (USA \& Canada) & -0.72 & 0.56 & 1.38 & 1.11 & -1.06 & 0.30 \\
\hline Australia & -0.03 & -1.72 & -1.25 & -0.43 & 2.07 & -0.33 \\
\hline Western Europe \& other high income countries & -0.59 & -0.11 & -0.47 & 0.51 & 0.39 & -0.05 \\
\hline Developing countries & 3.13 & 3.31 & 1.02 & 0.64 & -0.33 & 1.56 \\
\hline Developed countries & -0.70 & -0.37 & 0.16 & -0.58 & -0.21 & -0.33 \\
\hline World & 0.49 & 1.28 & 0.49 & 0.04 & -0.38 & 0.40 \\
\hline
\end{tabular}

Computed by authors based on FAOSTAT online database, 30 Dec. 2012

Wheat dominates world trade in agricultural commodities, with an imported volume of 144 million tons and total value of $\$ 36$ billion in 2010. This compares with 107 million tons imported for maize and 31 million tons for rice during the same period, with a total trade value of about $\$ 26$ billion and $\$ 20$ billion, respectively. The economic dependence of developing nations on wheat is indicated by the fact that it is their single largest food import and it is an important share of emergency food aid (Dixon et al. 2009). Annual net imports by developing countries during 20082010 averaged about 83.7 million tons of wheat (Fig. 2), which compares with 33.3 million tons for maize and -1.8 million tons for rice. ${ }^{3}$ Most of the larger producers such as India and China are largely self-sufficient and do not normally participate in international markets, except in abnormal years. Most of the countries in Africa, West Asia and SE Asia are net importers of wheat. The major exporters are US, Canada, Australia, Argentina, Ukraine, Kazakhstan and Russia. Historically, crop failure, high bread prices, and ergotism (a poisoning effect due to contamination by fungus-infected grain that is consumed when clean wheat is not available) have been cited as causes of the French Revolution (Hibbert 1980); and in modern times urban riots sparked by the wheat price hikes of 2007-8 (such as those

\footnotetext{
${ }^{3}$ The developing world is a net exporter of rice. In 2010, developing countries exported 26 million tons and imported 24.2 million tons which accounted for $80 \%$ of the global rice export and imports.
}

recently experienced in the 'Arab Spring' in North Africa and the Middle East) demonstrates the continued political significance of wheat (Trego 2011). Wheat prices, like maize and rice, have remained stable since October 2011 but since June 2012 appear to be rising again. ${ }^{4}$

Overall, people in developing countries consumed an average of $70 \mathrm{~kg} /$ per capita/year in 2005-2009, of which $84 \%$ was consumed directly as food and only $6 \%$ as feed, as compared to $190 \mathrm{~kg} / \mathrm{per}$ capita/year in higher income countries, with a food share of only $50 \%$ and $38 \%$ consumed as feed (Table 5). At the global level wheat is mainly used for food $(71 \%)$ and less than $20 \%$ is used for feed. However, wheat demand for feed is highest in regions where maize is not widely grown (e.g. Australia, $54 \%$ ) and seems to be increasing further as the narrowing price differentials with maize imports make domestically grown wheat more competitive for livestock feed (Table 5). The highest annual total per capita demand for wheat is in developed countries where more than a third of the wheat demand is used as feed for livestock. This ranges from $308 \mathrm{~kg}$ in Australia to $257 \mathrm{~kg}$ in Eastern Europe and Russia to $189 \mathrm{~kg}$ in Western Europe

\footnotetext{
${ }^{4}$ Prices for food staples went up during the second half of 2010 but started declining during 2011 but rising again in 2012. It is yet to be seen whether these rising price trends will be sustained during 2013. This new upward trend seems to be triggered by adverse climatic conditions (e.g. heat waves in the US grain belt, falling harvest prospects in Russia and Ukraine and delayed monsoons in the traditional wheat growing areas of South Asia).
} 
Table 4 Average annual total wheat demand growth rates (\%)

\begin{tabular}{|c|c|c|c|c|c|c|}
\hline Region & 1961-1970 & 1971-1980 & 1981-1990 & 1991-2000 & 2001-2009 & 1961-2009 \\
\hline E\&S Africa with RSA & 5.12 & 3.19 & 3.34 & 3.76 & 5.79 & 4.19 \\
\hline E\&S Africa without RSA & 6.29 & 3.44 & 3.87 & 4.36 & 7.63 & 5.04 \\
\hline Western \& Central Africa & 9.44 & 11.45 & -0.62 & 9.93 & 4.74 & 6.98 \\
\hline North Africa & 3.60 & 6.08 & 3.45 & 1.29 & 2.20 & 3.34 \\
\hline West Asia & 3.29 & 4.23 & 2.95 & 1.60 & 0.70 & 2.58 \\
\hline South Asia & 5.85 & 4.91 & 2.36 & 4.59 & 1.65 & 3.88 \\
\hline Southeast Asia \& Pacific & 12.03 & 6.07 & 1.59 & 8.00 & 4.25 & 6.31 \\
\hline East Asia & 8.23 & 7.02 & 4.43 & 0.84 & -0.05 & 4.09 \\
\hline Mexico and CAC & 5.44 & 4.96 & 1.70 & 2.42 & -0.13 & 2.89 \\
\hline Andean Region, South America & 2.79 & 4.04 & 2.18 & 3.42 & 2.15 & 2.94 \\
\hline Southern Cone, South America & 3.14 & 3.31 & 1.07 & 1.80 & 1.30 & 2.12 \\
\hline Eastern Europe \& Russia & 5.71 & 1.81 & 1.13 & -5.71 & 1.48 & 0.77 \\
\hline Central Asia & & & & -1.16 & 5.58 & 2.41 \\
\hline North America (USA \& Canada) & 2.82 & 0.58 & 5.68 & 0.46 & -0.91 & 1.76 \\
\hline Australia & 3.56 & 2.46 & 2.17 & 3.42 & 2.61 & 2.83 \\
\hline Western Europe \& other high income countries & 1.90 & 0.41 & 1.64 & 2.67 & 0.95 & 1.52 \\
\hline Developing countries & 5.34 & 5.28 & 3.09 & 2.74 & 1.37 & 3.57 \\
\hline Developed countries & 4.01 & 1.21 & 1.79 & -1.71 & 0.69 & 1.15 \\
\hline World & 4.47 & 2.84 & 2.37 & 0.61 & 1.03 & 2.24 \\
\hline
\end{tabular}

Computed by authors based on FAOSTAT online database, 30 Dec. 2012

and other high income countries. In North America total annual demand is about $120 \mathrm{~kg}$ per capita, of which about $70 \%$ is used for food, $20 \%$ for feed, and about $10 \%$ for industrial processing and other uses. ${ }^{5}$ Among the developing countries, Central Asia has the highest per capita demand $(322 \mathrm{~kg}$ ) but more than half is used as food and about a quarter used as feed, and the remaining balance used as seed and for industrial processing. About a third of the people living in Central Asia and the Caucasus survive on less than 2 USD/day, and they depend heavily on wheat for daily calories. Wheat also plays a major role in food security in North Africa (201 kg/capita) and West Asia (155 kg/capita: Table 5). The numbers of those living on under 2USD/day are much greater in North Africa and the Middle East because of higher population densities, and they also depend heavily on calories from wheat. Over $90 \%$ of the wheat consumed in South Asia is used as food, especially in Pakistan, Afghanistan and north India. Although a much larger number of people live in poverty (less than 2 USD/day) in South Asia,

\footnotetext{
${ }^{5}$ Globally, about $12 \%$ of wheat is used for uses other than food and feed. The properties that make wheat suitable in food products and starch also make wheat useful in non-food and industrial applications. Wheat gluten is unique due to its ability to be elastic, bind water and form films that can be stabilized with heat. These properties render wheat gluten useful for the preparations of adhesives, coatings, and polymers. Wheat is also used in making paper, cosmetics and pharmaceutical products.
}

wheat is also very important in East Asia where $84 \%$ is used as food (Table 5).

The structure of wheat demand is changing as wealthier populations consume more animal products (Pingali 2007) and as more urban populations choose easy-to-prepare, more refined wheat products over coarse grains and traditional staples (Dixon et al. 2009; Lobell and Burke 2010). Although most of the wheat in the developing world will continue to be consumed as food, preferences for the type of food products will become increasingly differentiated. Meng et al. (2009) report that the share of flour used for noodles and steamed bread is projected to decrease in China, with an increase in the share of western bread products, along with shifts to end-uses associated with convenience and "higher" quality. Similar patterns have been observed throughout Asia, North Africa and Latin America. The demand for certain high-value end uses including flour, pasta, and bakery products is expected to grow significantly. At the same time, increased industrial processing of traditional foods like chapatti and kuskus will require supplies of consistent and high quality grain. Breeding wheat with specific quality characteristics has the potential to add economic value, but realizing this potential requires investments in quality standards and institutional capacity to differentiate products in value chains. Except in a few developing countries, the demand for wheat is being met increasingly through imports. 
Fig. 2 Average annual net imports of wheat (million tons), 2008-2010. Source: Computed by authors based on FAOSTAT online database, 30 Dec. 2012

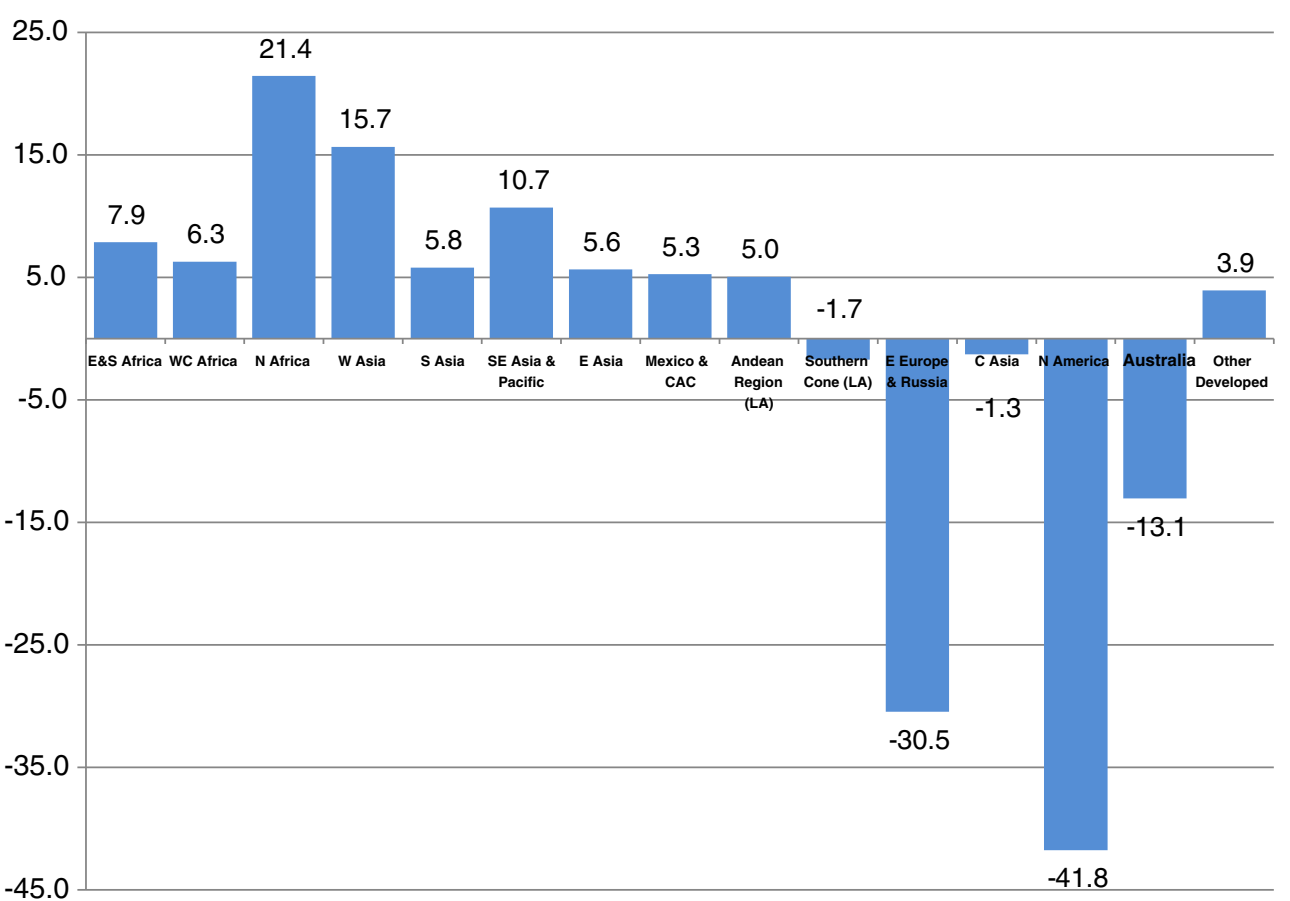

Finally, when exploring future trends, consideration could be given to the fact that animal feed demand shifts among protein sources depending on availability, quality and prices. The proportion of soya, wheat, barley and maize fed to animals varies each season, rendering accurate prediction of future demand difficult.
Historical patterns in wheat production and productivity

Beginning in the 1960s, the development and diffusion of high yielding, short-statured, fertilizer-responsive varieties of wheat, combined with expanded use of fertilizers and irrigation, led to dramatic yield increases in irrigated areas
Table 5 Average annual global wheat utilization by region (\%), 2005-2009

Computed by authors based on FAOSTAT online database, 30 Dec. 2012

\begin{tabular}{lcrrr}
\hline & $\begin{array}{c}\text { Total demand per } \\
\text { capita }(\mathrm{kg} / \mathrm{year})\end{array}$ & \multicolumn{2}{c}{ Share in total demand (\%) } \\
\cline { 3 - 5 } & & Food & Feed & Other uses \\
\hline E\&S Africa with RSA & 31.55 & 88.71 & 1.22 & 10.07 \\
E\&S Africa without RSA & 27.12 & 86.45 & 1.28 & 12.27 \\
Western and Central Africa & 17.07 & 95.60 & 0.46 & 3.94 \\
North Africa & 201.48 & 81.96 & 7.21 & 10.82 \\
West Asia & 155.03 & 78.39 & 5.99 & 15.63 \\
South Asia & 62.52 & 91.11 & 1.43 & 7.46 \\
Southeast Asia and Pacific & 21.65 & 91.42 & 5.94 & 2.64 \\
East Asia & 78.47 & 84.01 & 6.67 & 9.32 \\
Mexico and CAC & 48.35 & 71.77 & 4.94 & 23.29 \\
Andean Region, South America & 46.27 & 92.14 & 0.86 & 6.99 \\
Southern Cone, South America & 75.54 & 85.98 & 3.35 & 10.67 \\
Eastern Europe and Russia & 257.17 & 47.16 & 35.11 & 17.73 \\
Central Asia & 322.64 & 53.27 & 25.77 & 20.97 \\
North America (USA \& Canada) & 117.71 & 71.37 & 19.21 & 9.42 \\
Australia & 308.91 & 23.30 & 53.90 & 22.80 \\
Western Europe \& other high income countries & 189.41 & 45.86 & 45.33 & 8.82 \\
Developing countries & 69.24 & 83.57 & 5.87 & 10.55 \\
Developed countries & 190.01 & 49.86 & 37.68 & 12.46 \\
World & 91.76 & 70.53 & 18.18 & 11.29 \\
\hline
\end{tabular}


of Asia. This was followed by technological change in the rain-fed wheat-growing areas of Asia and Latin America and, more slowly, in the drier zones of the Middle East, North Africa, and Sub-Saharan Africa, where government policies were less supportive than they had been in Asia. About $50 \%$ of all wheat worldwide is now planted to the semi-dwarf varieties emanating from the international, collaborative plant breeding system of CIMMYT and national research institutions, reaching $89 \%$ in South Asia, $80 \%$ in West Asia and North Africa, $95 \%$ in Latin America and $90 \%$ for all developing regions (Lantican et al. 2005; Rejesus et al. 1999).

The impacts of these varietal changes were startling. Global production showed a dramatic annual growth of about $4.4 \%$ during the first decade (1960-70) of the Green Revolution, about $4 \%$ during the following decade, $3.2 \%$ during the third decade, stagnated during 1990-2000 and grew by $1.27 \%$ per annum during the last decade (2001-10). As a result, global production expanded from 222 million tons in 1961 to 674 million tons in 2008-10 (Fig. 3). ${ }^{6}$ Across Asia from 1961 to 1970 , total wheat production grew on average by $8.3 \%$ per year in South Asia, $8.5 \%$ in East Asia, and $8.6 \%$ in Mexico and Central America. This was sustained further during the following decade when wheat production annually increased by $5 \%$ in South Asia, $7.4 \%$ in East Asia, $5 \%$ in West Asia and $2.7 \%$ in Mexico and Central America (Table 6). By 1990, Byerlee and Traxler (1995) calculated that the economic surplus attributable to international wheat breeding efforts was 3.2 billion USD per year (at 2002 USD value). Based on 1997 data, the additional wheat production in developing countries directly attributable to international wheat breeding efforts ranged from 17 to 33 million tons per year, worth the equivalent of 2.0 to 4.0 billion USD (values converted to 2002 value). Using the 2002 data, Lantican et al. (2005) estimated that the additional amount of wheat produced in developing countries that is attributable to international wheat breeding research ranged from 13 to 41 million tons per year, with a value of 2.0 to 6.1 billion USD per year (2002 value).

Steady growth in world wheat production during the 20th century was due to both area expansion and yield increases, but these differed by region (Fig. 4). From 1966, yield was a more important source of production growth than area in most regions. Annual growth rates in wheat yield were positive overall in each region from 1961. Except in West Africa, where wheat is a new crop, the much higher growth rates of yield than area demonstrate the outstanding

\footnotetext{
${ }^{6}$ The major fall in production starting 1992 (left panel) is mainly because Central Asia, which was part of the former Soviet Union till 1991, is grouped under the developing countries. The developed countries will continue to dominate production and area if Central Asia is grouped under the developed countries (Figs. 3 and 5).
}

contribution of research during the past half century. The political changes in the 1990s in Eastern Europe and the former Soviet Union caused a partial collapse of the agricultural sector and therefore comparisons including the 1990s have to be interpreted very carefully. Result are sensitive to the countries included and the years used as endpoints (Aquino and Carrión 2009; Rejesus et al. 1999).

The global wheat area peaked in the early 1980 s, reaching about 240 million ha, declining gradually until the spike in wheat prices in 2007-8 (Fig. 5). At the global level, the wheat area grew at an average rate of $0.24 \%$ in the $1960 \mathrm{~s}, 1.34 \%$ in the $1970 \mathrm{~s},-0.23 \%$ in the $1980 \mathrm{~s},-0.68 \%$ in the 1990 s, and $0.12 \%$ during the recent decade (20012010). Wheat area represented an average of about a third of the cereal area and $27 \%$ of the production worldwide from 2007 to 2009. Except for the Andean Region, North America and parts of Western Europe, area growth rates remained positive among regions from 1961 to 1970. During the 1970s, area declined in Sub-Saharan Africa, in Mexico, the Andean Region, Eastern Europe and the former Soviet Union and Western Europe. From 1980 and into the 1990s, the wheat area approached its limit in South Asia and growth rates became negative in East Asia, Eastern and Southern Africa (due to area decline in South Africa) and high income countries, remaining negative in many countries of Eastern Europe and the former Soviet Union (Aquino and Carrión 2009). In recent years, wheat area has declined significantly in major wheat-producing countries such as the US and China as farmers have shifted to higher value crops, in particular maize (to meet increasing feed and biofuel demand) and soybean (Dixon et al. 2009: 3). Wheat area in the US has decreased from about 30 million ha throughout the 1990s to 22-24 million ha in recent years. This indicates that except in a few places where area growth may still be possible (see Section "Constraints to productivity growth"), physical expansion will not be the main source of supply of growth at the global level.

Over the past five decades, world wheat yields have grown at an average rate of $2.24 \%$ per annum since 1960 . Wheat yields have grown at average rate of $2.8 \%$ in developing countries, more than the rate achieved by higher income countries (2.2\%) (Table 7). As a result of the faster productivity growth, the average yield levels in the developing and developed regions in recent years are almost the same (Fig. 6). ${ }^{7}$ India, Pakistan, Argentina, Iran, Ukraine, China and Kazakhstan accounted for about $41 \%$ of total wheat area and production in 2008-2010. Among developing countries, the greatest yield growth was attained in East Asia (reflecting China, primarily),

\footnotetext{
${ }^{7}$ This is particularly the case if one assumes Central Asia as part of the developed world as the yields remain low at about $1.5 \mathrm{t} / \mathrm{ha}$ in this region (Fig. 6).
} 
Fig. 3 Historical trends in wheat production (million tons), 1961-2010. Source: Computed by authors based on FAOSTAT online database, 30 Dec. 2012

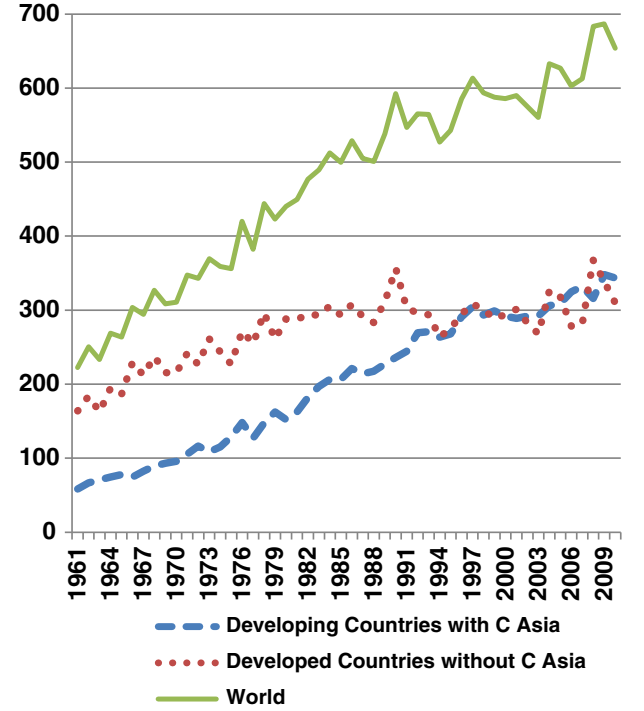

North Africa, South Asia (reflecting India, in particular), West Asia and Eastern and Southern Africa, primarily in Ethiopia and South Africa. The Andean Region of South America and West and Central Africa are at the other extreme (Table 7).

The significant jump in productivity in the post 1960s period signals the effect of the Green Revolution on yield levels and growth rates in the developing countries. Average wheat yields differed dramatically between developed and developing countries before the Green Revolution (from 1951 to 1966), when they grew at an average of $2.2 \%$ per annum in developed countries and only $0.9 \%$ per annum in developing countries (Aquino and Carrión 2009). The average annual growth rate in yields jumped to $3.6 \%$ in developing countries during the Green Revolution (1966-1979), dropping to $2.8 \%$ from 1980 to 94 and about $1 \%$ in the most recent decade (Aquino and Carrión 2009; Fischer et al. 2009). Turning points on growth rates are visible in both developing and industrialized countries at about 1990.

The growth rate of yield both before and since the Green Revolution has lagged behind that of population, although constrained purchasing power among poorer consumers

Table 6 Average annual wheat production growth rate by region (\%)

\begin{tabular}{|c|c|c|c|c|c|c|}
\hline Region & $19961-70$ & $1971-80$ & $1981-90$ & $1991-00$ & $2001-2010$ & $1961-2010$ \\
\hline E\&S Africa with RSA & 6.05 & 0.65 & 4.55 & 2.99 & 3.35 & 3.47 \\
\hline E\&S Africa without RSA & 4.88 & 0.44 & 4.94 & 0.65 & 8.87 & 3.94 \\
\hline Western \& Central Africa & 3.27 & 2.27 & 19.88 & 5.98 & 1.11 & 6.57 \\
\hline North Africa & 8.13 & 2.57 & 5.81 & 6.00 & 8.01 & 6.06 \\
\hline West Asia & 3.14 & 5.05 & 3.17 & 0.22 & 3.72 & 3.06 \\
\hline South Asia & 8.30 & 5.03 & 4.41 & 4.39 & 0.74 & 4.50 \\
\hline East Asia & 8.48 & 7.37 & 6.15 & 0.40 & 1.61 & 4.73 \\
\hline Mexico and CAC & 8.59 & 2.69 & 5.12 & -0.66 & 1.40 & 3.32 \\
\hline Andean Region, South America & -3.00 & -3.08 & 3.57 & 2.87 & 4.04 & 0.96 \\
\hline Southern Cone, South America & 3.72 & 6.14 & 4.60 & 3.65 & 4.31 & 4.50 \\
\hline Eastern Europe \& Russia & 6.96 & 2.76 & 1.86 & -4.87 & 6.91 & 2.64 \\
\hline Central Asia & & & & 0.29 & 4.11 & 2.41 \\
\hline North America (USA \& Canada) & 1.64 & 6.86 & 3.54 & -1.61 & 1.13 & 2.32 \\
\hline Australia & 10.58 & 9.53 & 12.19 & 10.10 & 13.78 & 11.25 \\
\hline Western Europe \& other high income countries & 3.35 & 4.56 & 3.22 & 1.90 & 0.91 & 2.78 \\
\hline Developing countries & 5.72 & 5.24 & 4.58 & 2.23 & 1.72 & 3.86 \\
\hline Developed countries & 3.80 & 3.60 & 2.32 & -1.67 & 1.34 & 1.84 \\
\hline World & 4.15 & 3.91 & 3.11 & 0.00 & 1.27 & 2.45 \\
\hline
\end{tabular}

Computed by authors based on FAOSTAT online database, 30 Dec. 2012 
Fig. 4 Average annual area and yield growth rates (\%/year), 1961-2010. Source: Computed by authors based on FAOSTAT online database, 30 Dec. 2012

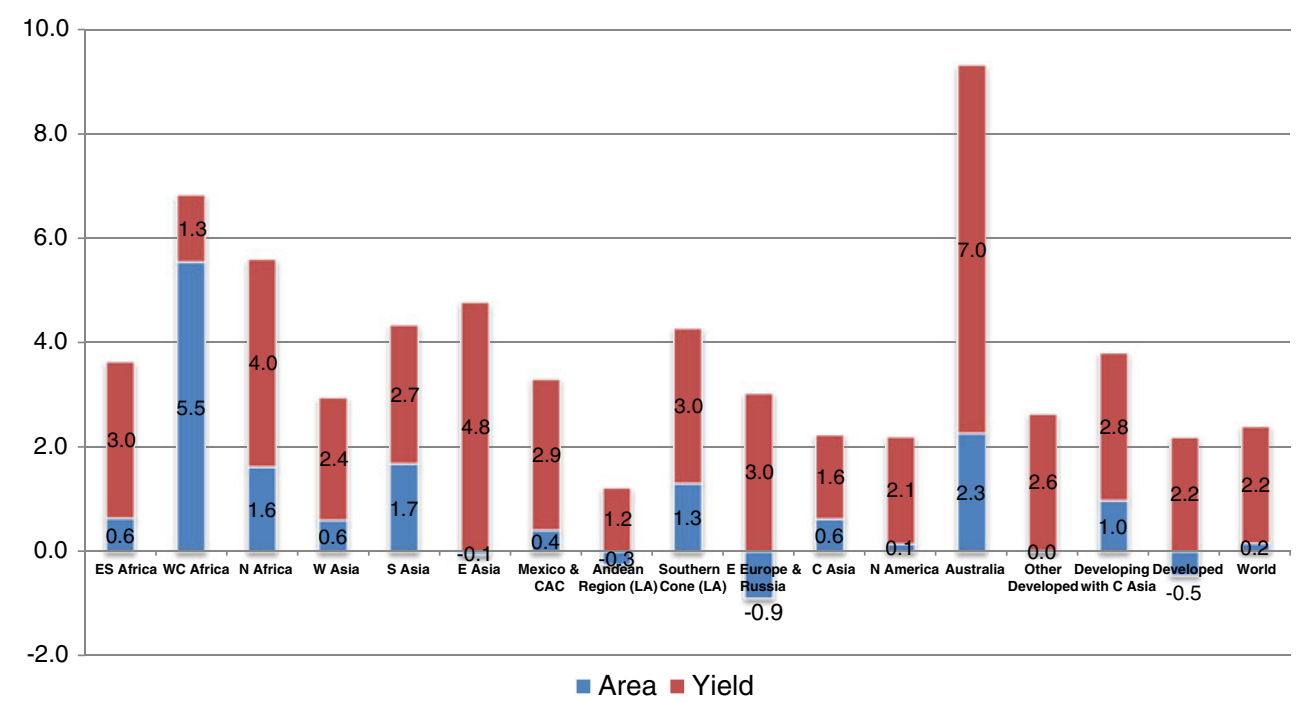

means that rates of growth in effective demand may also have lagged behind population growth. Dixon et al. (2009) have offered several explanations for the lagging growth of yield. Along with problems related to resource degradation, real international wheat prices have declined until very recently (Fig. 7). Private sector investments rose slowly; oil prices drove up the cost of fertilizer and pumping irrigation water; droughts became more frequent in countries such as Australia; and quality of irrigation water and soils worsened. Wheat prices spiked in 2007 when climatic conditions worsened in Australia, Canada and China and demand for crops to convert into biofuels soared in the US and Western Europe. The latter diverted land areas to maize and canola production. Global wheat stocks fell to 125 million tons, the smallest amount since 1981 (USDA/ERS 2011).
In addition to improvements in average yields, unlike in some other cereals, the variability of world wheat production declined as average production rose from the 1960s to the 1970s (Hazell 2010). In South Asia, wheat yields became more stable as mean yields increased (Singh and Byerlee 1990). Most recently, based on a comprehensive data set of wheat adoption rates by country from 1960 to 2000, Gollin (2006) found a "striking decline" in the variation of wheat yields relative to yield levels over this entire period for developing countries. Although causality cannot be attributed to wheat research, the author's analysis confirms a negative correlation between use of modern wheat varieties and the variability of wheat yields, even when use of irrigation and other inputs are taken into account. This indicates that modern varieties reduced yield variability from year
Fig. 5 Historical trends in wheat area (million ha), 19612010. Source: Computed by authors based on FAOSTAT online database, 30 Dec. 2012

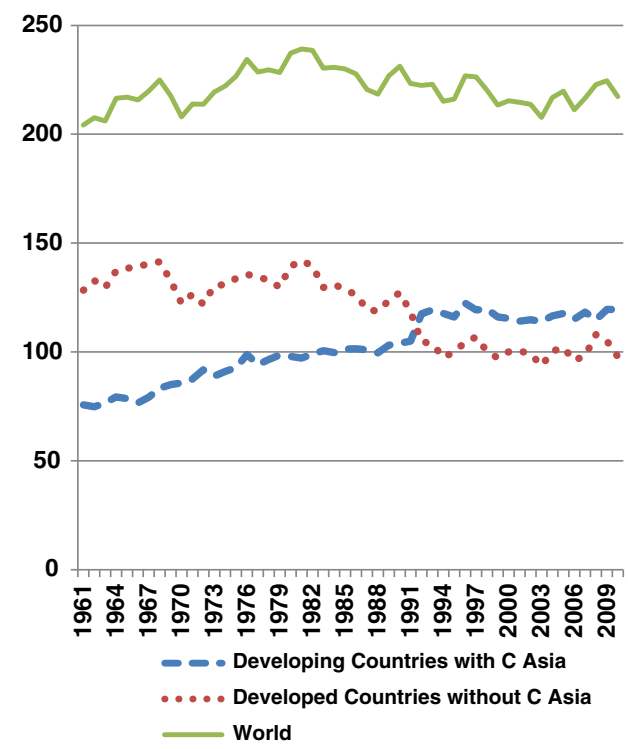


Table 7 Average annual wheat yield growth rates (\%)

\begin{tabular}{|c|c|c|c|c|c|c|}
\hline Region & $19961-70$ & $1971-80$ & $1981-90$ & $1991-00$ & $2001-2010$ & $1961-2010$ \\
\hline E\&S Africa with RSA & 2.38 & 3.30 & 3.75 & 3.95 & 1.55 & 3.00 \\
\hline E\&S Africa without RSA & 1.49 & 4.58 & 2.71 & -1.48 & 4.08 & 2.29 \\
\hline Western \& Central Africa & -0.43 & 2.27 & -3.32 & 5.86 & 1.86 & 1.28 \\
\hline North Africa & 5.41 & 3.05 & 5.71 & 1.27 & 4.59 & 3.98 \\
\hline West Asia & 1.47 & 4.37 & 2.70 & 0.42 & 2.72 & 2.35 \\
\hline South Asia & 4.52 & 2.25 & 3.45 & 2.96 & 0.30 & 2.66 \\
\hline East Asia & 8.59 & 5.79 & 5.53 & 1.84 & 2.48 & 4.77 \\
\hline Mexico and CAC & 7.41 & 2.78 & 1.56 & 2.02 & 1.13 & 2.89 \\
\hline Andean Region, South America & 1.01 & -0.96 & 2.50 & 0.52 & 3.03 & 1.23 \\
\hline Southern Cone, South America & 2.28 & 1.44 & 3.45 & 3.60 & 4.03 & 2.97 \\
\hline Eastern Europe \& Russia & 6.24 & 3.06 & 3.76 & -1.00 & 3.42 & 3.03 \\
\hline Central Asia & & & & 1.89 & 1.39 & 1.61 \\
\hline North America (USA \& Canada) & 5.19 & 0.62 & 2.34 & 0.78 & 1.65 & 2.05 \\
\hline Australia & 6.09 & 3.15 & 11.86 & 4.24 & 9.79 & 7.05 \\
\hline Western Europe \& other high income countries & 3.38 & 4.59 & 2.97 & 1.56 & 0.67 & 2.62 \\
\hline Developing countries & 4.26 & 3.62 & 3.94 & 1.14 & 1.33 & 2.83 \\
\hline Developed countries & 4.16 & 2.10 & 3.17 & 0.60 & 1.09 & 2.19 \\
\hline World & 3.85 & 2.46 & 3.33 & 0.64 & 1.09 & 2.24 \\
\hline
\end{tabular}

Computed by authors based on FAOSTAT online database, 30 Dec. 2012

to year and therefore contributed to reduction of risk and vulnerability of farmers.

\section{Constraints to productivity growth}

Stark differences in productivity characterize today's wheat farming systems, reflecting agro-ecological variation and input use. Although average yields are slightly higher in the developed countries, more than $95 \%$ of wheat produced in these countries is rain-fed (Dixon et al. 2009). On the other hand, about $90 \%$ of all irrigated wheat globally is produced in developing countries and nearly $60 \%$ of wheat in these countries is irrigated, particularly in South Asia (India, Pakistan, Bangladesh and Nepal), West Asia (Iran and Afghanistan), Central Asia (Uzbekistan, Turkmenistan, Kyrgyzstan, Tajikistan and southern Kazakhstan), North Africa (Egypt and Sudan), China and Mexico (Sayre and
Fig. 6 Historical trends in wheat yield (ton/ha), 1961-2010. Source: Computed by authors based on FAOSTAT online database, 30 Dec. 2012
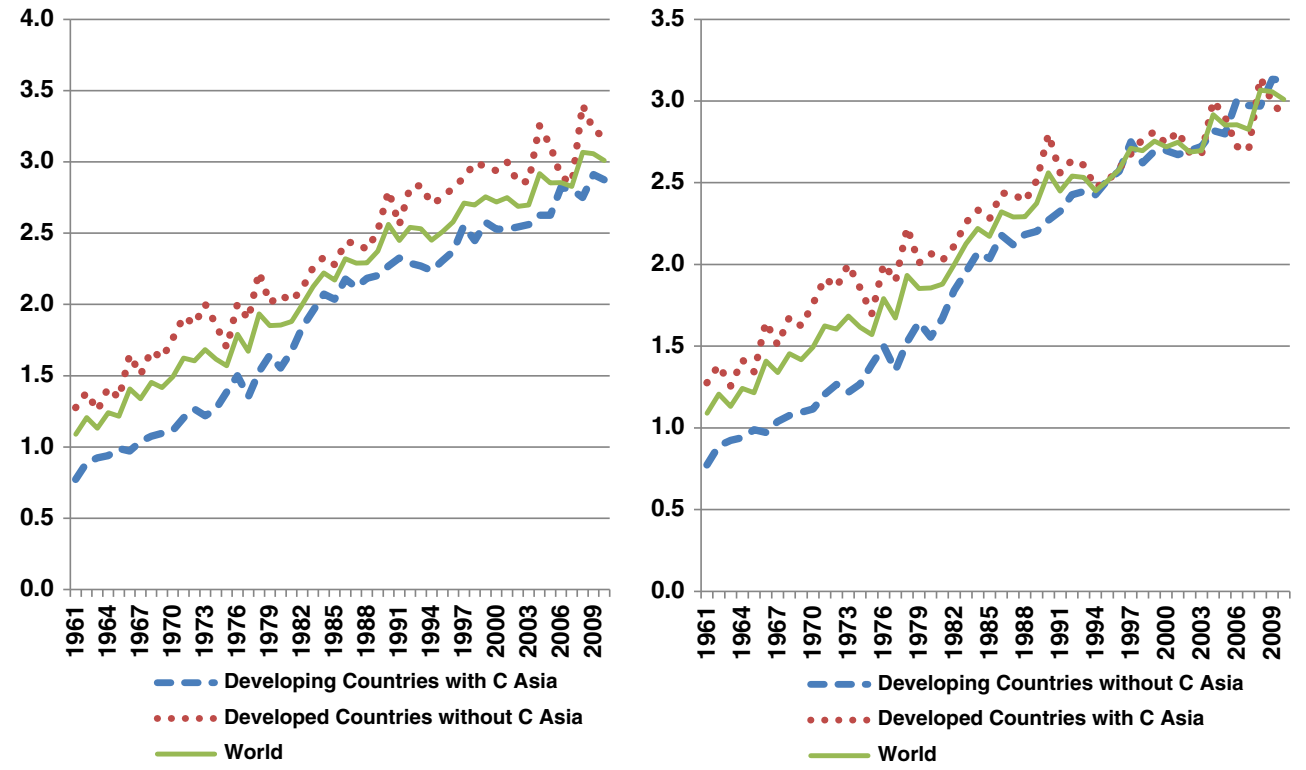


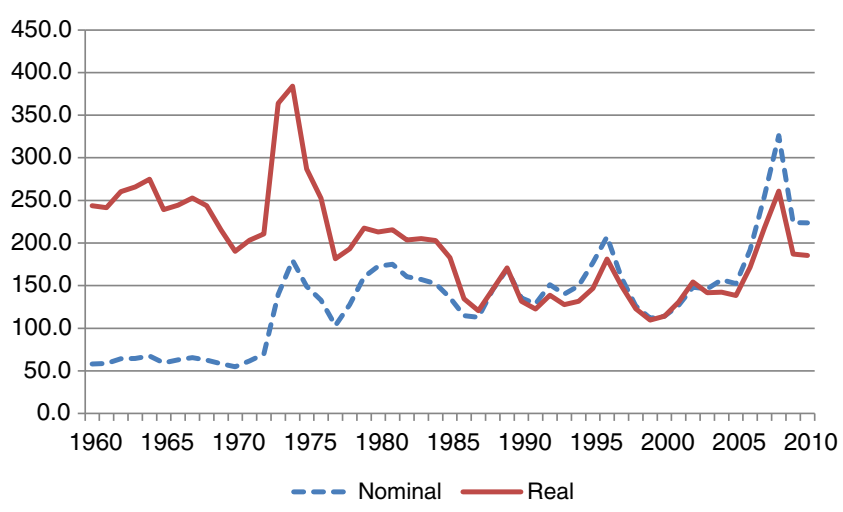

Fig. 7 Nominal and real wheat prices, 1960-2007 (US HRW \$/mt). Source: World Bank/IMF. Deflated by international manufacturers unit value index

Govaerts 2009). National average yields among rain-fed producers range from $0.9 \mathrm{t} / \mathrm{ha}$ in Kazakhstan to about $9 \mathrm{t} / \mathrm{ha}$ in Ireland, Belgium and the Netherlands (Dixon et al. 2009). Production costs also vary widely, even within major producing countries. For example, data from the most recent Agricultural Resource Management Study in the US shows costs of producing wheat per hectare and per tonne varied greatly among wheat growers, reflecting differences in agronomic practices and yields. A low proportion of producers covered all their costs raising questions about the viability of many (Ali and Vocke 2002).

More than a decade ago, it was evident that expansion in land area sown to wheat would no longer contribute significantly to future increases in wheat production; future increases in productivity would rely almost exclusively on the use of inputs by farmers and technological advances (Rejesus et al. 1999). That conclusion remains valid unless investment in irrigation can be expanded to bring new land into production, although there is some evidence of unexploited land potential. Considering 2005 prices, and areas not currently cultivated or forested and within six hours to the nearest market, a recent study by the World Bank found about 71 million ha of additional land suitable for wheat production (Deininger et al. 2010). Most of this land (in million ha) is found in Europe and Central Asia (39.5), followed by Latin America (11.0), Sub-Saharan Africa (3.8), the Middle East and North Africa (2.6), and in East and South Asia (1.1), with the remainder scattered elsewhere. The Russian Federation and Argentina stand out in terms of uncultivated land areas that are suitable for wheat production. Little land appears to be available among other current producers, but Deininger et al. (2010) argue that for many countries with expansion potential, and for some large producers, the scope for increasing yields is considerable. With yields of under $1 \mathrm{t} / \mathrm{ha}$, Kazakhstan cultivates 13 million ha of wheat and has an additional 2.8 million ha potentially available for expansion.
The costs of two of the most important physical inputs for wheat production-water in developing countries and fertilizer globally - are rising and expected to continue to rise as fossil fuels and water become increasingly scarce. Growth in irrigated wheat area began to slow during the 1980s in India due to water constraints but reached $100 \%$ area under irrigation in the Yaqui Valley of Mexico. Other major exporters, such as North America, Argentina, Australia, and Europe grow rain-fed wheat. Although estimates suggest that wheat is the most water use efficient of the world's three major cereals, the variation in water use efficiency in wheat ranges from 700 to 5,0001 to produce $1 \mathrm{~kg}$ of grain (Dixon et al. 2009). For this reason, experts predict that irrigation water will be used more in the future for high value crops, and the locus of wheat production will shift to more extensive rain-fed systems, especially in Kazakhstan and Russia and the Southern Cone of Latin America (Dixon et al. 2009).

Analyzing data from the International Fertilizer Association, Heisey and Norton (2007) found that wheat is the largest single crop for use of fertilizer, consuming $16.7 \%$ in developing countries, $24.1 \%$ in transitional, and $20.2 \%$ in industrialised countries, or $18.1 \%$ worldwide. Data indicate that application rates are similar across these groups, however, with an average of $127 \mathrm{~kg}$ of nutrients per ha planted. Rates are considerably higher in China and Western Europe, where policies support intense input use. Application rates are closer to the world average in India and other wheat growing countries in Asia, in Canada, Latin America and the US, and are lowest in the Middle East, North Africa, and Sub-Saharan Africa but with great differences in Nitrogen Use Efficiency (NUE). This is $50 \%$ less in China, India and Pakistan than Europe or the US (Table 8). However, among a sample of countries surveyed by CIMMYT (Aquino and Carrión 2009), fertilizer costs (USD/ha) incurred by farmers are highest in Rwanda, Zambia and Madagascar; lowest in Mongolia, some countries of Central and South Asia and the Asian subcontinent as well as under minimum till conditions in Argentina. The nitrogen to grain price ratio, a more complete indicator of incentives to use fertilizer, has long been high in countries of Sub-Saharan Africa mainly due to high transport costs for imported inputs, but also in the Southern Cone of Latin America (Rejesus et al. 1999: 14; Aquino and Carrión 2009). The consensus view has been that over much of South Asia, diminishing marginal returns to increased fertilizer application were already apparent in the late 1980s (Byerlee 1992). In the US and Europe, improved nitrogen management rather than increased nitrogen use has been recommended since the early 1990s.

Agrochemicals appear to represent a larger cost burden for farmers in Western Europe than for farmers in other regions of the world. For example, data analysed by Oerke and Dehne (2004) show expenditure on various chemical 
Table 8 Nitrogen application ( $\mathrm{kg} / \mathrm{ha})$, average cereal yields $(\mathrm{kg} / \mathrm{ha})$ and NUE $(\mathrm{kg}$ grain per kg N), 2006-2007

FAOSTAT-2007; IFA-2009

\begin{tabular}{|c|c|c|c|c|c|c|c|c|c|}
\hline \multirow[t]{2}{*}{ Region } & \multicolumn{3}{|c|}{ Wheat } & \multicolumn{3}{|l|}{ Rice } & \multicolumn{3}{|c|}{ Maize } \\
\hline & $\mathrm{N}$ & Yield & NUE & $\mathrm{N}$ & Yield & NUE & $\mathrm{N}$ & Yield & NUE \\
\hline China & 197 & 4489 & 23 & 192 & 6422 & 33 & 180 & 5378 & 30 \\
\hline India & 117 & 2619 & 22 & 106 & 3302 & 31 & 45 & 1907 & 42 \\
\hline Pakistan & 140 & 2519 & 18 & 146 & 3318 & 23 & 123 & 2906 & 24 \\
\hline EU-15 & 135 & 5911 & 44 & 125 & 6693 & 54 & 227 & 8723 & 38 \\
\hline US & 86 & 2603 & 30 & 163 & 8019 & 49 & 152 & 9360 & 62 \\
\hline World & 97 & 2825 & 29 & 101 & 4211 & 42 & 98 & 4429 & 45 \\
\hline
\end{tabular}

crop protection products for major crops approached 100 USD/ha in West Europe, (most of which is herbicides and fungicides) compared to slightly over $40 \mathrm{USD} /$ ha in North America (most of which is herbicides) followed by around 30 USD/ha in the Far East, less in Latin America (under 10 USD/ha) and in the countries they group under Eastern Europe and lowest in the rest of the world. However, the data on which they base their estimates are from 1998 sources.

In general, and specifically in developing countries, less pesticide (fungicides, insecticides) is applied to wheat than many other crops, although herbicides are more widely used. Among developing countries, China is known to be a heavy consumer of pesticides. Singh et al. (2003) reported that India is the second largest manufacturer of pesticides in Asia. Pesticide use in India is also highly skewed towards cotton (40\%), followed by rice (14\%) and vegetables ( $8 \%$ ). Wheat consumes $6 \%$, followed by pulses and tea (Singh et al. 2003: 211). Lower pesticide use in developing countries reflects a long-standing focus on breeding for genetic resistance to wheat pests and diseases. For example, CIMMYT's Global Wheat program spends close to $50 \%$ of its investment in wheat improvement on breeding for improved disease resistance.

\section{Biotic constraints}

Biotic constraints for wheat production include economic losses from diseases caused by various pathogens, insects and weeds. Although weeds are the most important pests of wheat, the incidence and impact of pathogens such as the rusts increase with cropping intensity, monocropping and uniformity in the genes conferring resistance among the varieties grown. Losses vary considerably by region, and the devastating losses from wheat rust in India were a motivation for early plant breeding. Rust epidemics causing losses exceeding 50 million USD per annum occurred during the last decade at least once in all major wheat growing countries where fungicide application is not a routine practice. (CIMMYT 2011)

Recent rust epidemics have occurred in Australia (1993), China (2010), Ethiopia (2010), India (2010), Iran (1992,
2007, 2009), Kenya (2009), Mexico (2003), Pakistan (1993, 1994, 2005), the Southern Cone of Latin America (several during the last two decades), Syria (2010), Turkey (1992, 1996), USA (1993, 2000) and Uzbekistan (1998, 2009, 2010). A particular concern is the threatening emergence (in Uganda) of a new strain of stem rust referred to as Ug99 (Singh et al. 2011).

Under current pest and disease control practices, annual losses to pathogens, pests, and viruses in developing countries are estimated at $13 \%$ (Oerke 2006), equivalent to 45 million tons of wheat per year, valued at about 9 billion USD in 2006 prices. Climate change and globalization come with new risks of pest and disease outbreaks (Legrève and Duveiller 2010). Post-harvest losses and deterioration in quality are significant and are additional risks for food security particularly in developing countries lacking adequate infrastructure for grain storage. ${ }^{8}$ Food safety should also not be underestimated as pre-harvest mycotoxin contamination due to deoxynivalenol (DON) produced by Fusarium species may increase in warmer humid areas where wheat is grown after maize under reduced tillage. This affects the wheat value chain and reduces incomes for farmers besides increasing the risks to human and animal health (Duveiller et al. 2007).

Among all wheat diseases, the three rusts caused by the Puccinia triticina (leaf rust), $P$. striiiformis (yellow rust) and $P$. graminis (stem rust) are the most important. These pathogens have a high reproductive rate, spread over long distances in short time periods, and evolve new pathotypes rapidly. This is a threat to food security if susceptible varieties are grown in areas where access to chemical protection is either unavailable or not affordable (Duveiller et al. 2007). Although major epidemics of leaf rust have been averted in recent decades through breeding for durable resistance, the emergence of the stem rust Ug99 lineage in East Africa and its spread to other countries in Africa and Asia demonstrates that biotic stresses must not be overlooked. Ug99 has been recognized as a major

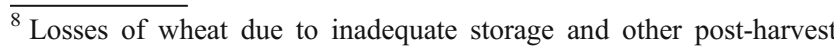
factors at the farm, village and commercial levels of up to $4 \%$ have been reported (Payne 2002).
} 
threat to global food security because of the susceptibility of $90 \%$ of the wheat varieties grown worldwide (Singh et al. 2011). The spread in recent years of strains of yellow rust virulent on varieties carrying the $Y r 27$ gene in west and central Asia is another example illustrating that there is a need to guard against complacency if a food crisis is to be avoided, in particular in times of increasing cereal prices and market uncertainties. Early rust epidemics are particularly feared by farmers as they may cause yield losses of $50 \%$ to $100 \%$ (in the case of stem rust). Identification and transfer of new sources of resistance in broadly-adapted high yield wheat genotypes are underway as a result of significant research investment through The Borlaug Global Rust Initiative; the replacement of susceptible varieties is the highest priority (Joshi et al. 2011; Singh et al. 2011). Delivering durable resistance to pathogens and pests that rapidly evolve new pathotypes is a priority. In this context, it has been suggested that genes which confer resistance which is race non-specific and characterised by "slow rusting" expression in adult plants may provide durable control (Singh et al. 2011). Beside the emergence of new races or pathotypes, new emerging diseases per se are a concern and should receive more attention under climate and global change scenarios. A recent example is wheat blast caused by Magnaporthe grisea. This is a new pathogen of wheat identified for the first time in Brazil in 1985. This disease is restricted to parts of South America and a recent epidemic in 2009 (causing yield losses of up to $100 \%$ in Paraná, Brazil) has shown that it could become devastating in rainy years as resistance to the pathogen is extremely limited and fungicides are largely ineffective (Duveiller et al. 2010).

Concerns about food safety require attention to be given to Fusarium head blight (FHB) or scab caused principally by F. graminearum (Teleomorph: G. zeae) (Duveiller et al. 2007). The fungus produces DON or vomitoxin, a mycotoxin that can lead to significant price penalties, reduced trading value and rejection of wheat flour by millers if the level of contamination is above authorized limits. FHB reemerged as a major wheat disease in the 90 s and receives a great deal of attention in China and high rainfall wheat growing areas. Development of resistance based on minor genes in high yielding broadly adapted germplasm is a primary objective.

Among foliar leaf pathogens affecting food security in developing countries, spot blotch caused by Cochliobolus sativus is of major importance in warm wheat growing areas of South Asia and in particular the eastern Gangetic plains where millions of resource-poor farmers grow wheat after rice and can face up to $15 \%$ yield reduction (Duveiller and Sharma 2009). This chronic wheat disease is exacerbated by abiotic stresses and typically affects marginal farmers who are less able to sow crops in a timely manner or apply adequate level of fertilizer. While the areas for optimum wheat cultivation in South Asia are expected to decline in the future as a result of changing climate, yield losses to spot blotch are expected to increase. Tan spot is a stubble-borne disease caused by Pyrenophora tritci-repentis and can cause major yield losses in Australia. The severity is particularly high under zero tillage because the pathogen survives on residues; tan spot is likely to increase in severity in developing countries adopting conservation agriculture. More attention will be required to include genetic resistance to this disease and to develop cropping systems that minimize the survival of inoculum. Lastly, Septoria diseases caused by Mycosphaerella graminicola and Stagonospora nodorum may cause serious losses in countries where farmers have no access to fungicides, in particular in North Africa and Ethiopia (Duveiller et al. 2007).

Climate change is also expected to increase threats from insects and soilborne pathogens in areas already affected by drought, particularly in West Asia and North Africa (Duveiller et al. 2007). Table 9 summarizes biotic constraints of priority for wheat research according to major wheat growing regions based on NARS and CGIAR scientists' experience in recent decades and taking account of expected new trends under a changing climate (Legrève and Duveiller 2010). Appropriate measures to limit the trans-boundary spread of pathogens and pests combined with investment in resistance breeding and adoption of sustainable cropping and integrated pest management systems are needed to mitigate the effects of biotic stresses on food security.

\section{Abiotic constraints}

The main detrimental effects of abiotic stress in wheat growing environments will be increased drought and heat stress. Wheat typically shows a linear reduction in yield with reduced water availability unless severe stress occurs at a critical growth stage or in combination with other stresses, in which case productivity may decline more drastically. Plants respond to water stress by lowering the rate of transpiration thereby reducing carbon fixation rate and growth. Extreme water deficit leads to tissue dehydration, potentially resulting in damage to the photosynthetic apparatus and other metabolic processes (Hsiao 2003). Water deficit is especially detrimental to reproductive growth, leading to floret sterility and/or inadequate levels of assimilation to sustain seed growth (Barnabas et al. 2008) depending on the timing of the stress.

Supra-optimal temperatures accelerate growth and development rates, and in combination with a concomitant reduction in leaf area, also reduce carbon fixation and growth. For example, wheat loses $3-4 \%$ of yield per ${ }^{\circ} \mathrm{C}$ above the optimum daytime temperature of $15^{\circ} \mathrm{C}$ (Wardlaw et al. 1989). However, when sufficient water is available, plant organs may be several degrees lower than air temperature due to evaporative cooling. Nonetheless, plants functioning outside of optimal temperature ranges will experience metabolic inefficiencies (Burke et al. 1988) some of which may directly affect grain filling. Increased 
Table 9 Regional priorities for biotic stress research initiatives in wheat

\begin{tabular}{|c|c|c|c|c|c|c|c|c|c|}
\hline $\begin{array}{l}\text { Biotic } \\
\text { stress }\end{array}$ & $\begin{array}{l}\text { East } \\
\text { Asia }\end{array}$ & $\begin{array}{l}\text { South } \\
\text { Asia }\end{array}$ & $\begin{array}{l}\text { West } \\
\text { Asia }\end{array}$ & $\begin{array}{l}\text { Middle East } \\
\text { North Africa }\end{array}$ & $\begin{array}{l}\text { Central Asia/ } \\
\text { Cauc asus }\end{array}$ & $\begin{array}{l}\text { Sub-Saharan } \\
\text { Africa }\end{array}$ & $\begin{array}{l}\text { Latin } \\
\text { Amer. incl. } \\
\text { Mex }\end{array}$ & $\begin{array}{l}\text { Vulnerable areas } \\
\text { with significant } \\
\text { loss (million ha) }\end{array}$ & $\begin{array}{l}\text { Developed } \\
\text { countries }\end{array}$ \\
\hline Leaf rust ${ }^{\mathrm{a}}$ & ++ & +++ & +++ & +++ & +++ & ++ & +++ & 50 & ++ \\
\hline Stem rust ${ }^{b}$ & +++ & +++ & +++ & +++ & +++ & +++ & +++ & 50 & +++ \\
\hline Yellow rust & +++ & ++ & +++ & +++ & +++ & +++ & + & 40 & +++ \\
\hline $\begin{array}{l}\text { Fusarium head } \\
\text { blight }^{\mathrm{c}}\end{array}$ & +++ & 0 & + & 0 & 0 & 0 & ++ & 10 & +++ \\
\hline Septoria & + & 0 & ++ & +++ & ++ & ++ & ++ & 11 & +++ \\
\hline Spot blotch & + & ++ & 0 & 0 & 0 & + & + & 11 & 0 \\
\hline Nematodes & ++ & ++ & +++ & ++ & 0 & + & + & 10 & + \\
\hline Tan $\operatorname{spot}^{\mathrm{d}}$ & 0 & + & 0 & + & +++ & 0 & ++ & 7 & ++ \\
\hline Smuts and bunts ${ }^{\mathrm{e}}$ & + & + & ++ & ++ & + & + & + & 5 & 0 \\
\hline Wheat blast ${ }^{\mathrm{f}}$ & 0 & 0 & 0 & 0 & 0 & 0 & + & 1 & 0 \\
\hline Powdery mildew & ++ & + & 0 & 0 & 0 & 0 & + & 6 & ++ \\
\hline $\begin{array}{l}\text { Root diseases }{ }^{\mathrm{g}} \\
\text { Insects }\end{array}$ & ++ & + & ++ & ++ & + & + & + & 9 & + \\
\hline Sunn pest & 0 & 0 & +++ & + & ++ & 0 & 0 & 10 & + \\
\hline Hessian fly & 0 & 0 & 0 & +++ & + & 0 & 0 & 2 & + \\
\hline $\begin{array}{l}\text { Russian wheat } \\
\text { aphid }\end{array}$ & 0 & 0 & + & + & + & ++ & + & 2 & + \\
\hline $\begin{array}{l}\text { Green bug and } \\
\text { other common } \\
\text { aphids }\end{array}$ & ++ & ++ & 0 & ++ & + & + & + & 10 & + \\
\hline $\begin{array}{l}\text { BYDV and other } \\
\text { viruses }^{\mathrm{h}}\end{array}$ & + & + & + & + & + & + & + & 4 & \\
\hline
\end{tabular}

${ }^{\text {a }}$ Leaf rust is currently under genetic control in Asia and Africa, but without maintenance breeding it is a major threat

${ }^{\mathrm{b}} \mathrm{Ug} 99$ is currently confined to Ethiopia, Kenya, Uganda, Sudan, Yemen, and Iran; but poses threats to global wheat production

${ }^{\mathrm{c}}$ FHS is expected to expand with conservation agriculture and maize-wheat rotation

${ }^{\mathrm{d}}$ Currently mainly important in Latin America and Central Asia, but will increase with expansion of zero-tillage

${ }^{\mathrm{e}}$ Historically important but effective and inexpensive seed treatments widely used

${ }^{\mathrm{f}}$ Only of local importance in Brazil, Paraguay, and Bolivia; however the fungus is the same species as rice blast and could potentially pose a threat to wheat production in warm areas of Asia where wheat-rice is grown; no resistance in wheat and limited tolerance

${ }^{\mathrm{g}}$ Includes sharp eye spot

${ }^{\mathrm{h}}$ Of local importance but currently not prioritized in CGIAR breeding programs due to resource limitations

rates of dark respiration are a major source of lost crop productivity at high night temperature, and remain an important challenge to stabilize the productivity of wheat and other staple crops as the climate gets warmer (Mohammed and Tarpley 2009). Short-term extreme increases in temperature of 5 to $10{ }^{\circ} \mathrm{C}$ can have catastrophic effects on yield especially when occurring at critical stages of development. This is not exclusive to cool season crops such as wheat but is also seen in heat adapted species such as rice (Wassmann et al. 2009) and will represent a unique challenge for crop improvement if the frequency of extreme climatic events increase as climate becomes more variable. Similar to the response to water deficit, high temperature stress can also lead directly to sterility by impairing meiosis, gametogenesis, and fertilization (Barnabas et al. 2008). At suboptimal levels of soil fertility, heat and drought stress can also lead to or exacerbate nutrient deficiencies (Bagci et al. 2007).

Another abiotic constraint for wheat production is salinity related to irrigation in the drier regions. This problem is expected to increase in intensity with increasing water shortages and scarcity. Climate change is expected to reduce water availability in general, making the use of unsustainable irrigation practices (including application of low quality water) more common, therefore increasing salinity problems (Bates et al. 2008). Climate change may increase inundation events associated with runoff from heavy rains, while sea level rise will increase levels of salinity and inundation in coastal regions. It is clear that adaptation measures will require a combination of genetic and system-wide strategies to address the abiotic constraints related to drought, heat, salinity 
and other stresses caused by climate variability and change (see below).

\section{Vulnerability to climate change}

Although considered a temperate species, wheat is the most widely grown of any crop cultivated annually in environments ranging from very favourable in Western Europe to severely stressed in parts of Asia, Africa, and Australia (Braun et al. 2010). Effects of climate change will therefore vary greatly depending on region. However, at a global level, Lobell et al. (2011) estimated that rising temperatures since 1980 have already lowered wheat yields by $5.5 \%$ without considering the effect of increasing $\mathrm{CO}_{2}$ levels (carbon fertilization) and by $2.5 \%$ considering C-fertilization. Global warming is likely to increase productivity as well as open up new cropping opportunities at high latitudes in vast areas of Canada and Russia, for example. However, since wheat yields decline at supra-optimal temperatures (Wardlaw et al. 1989) significant breeding effort will be required to maintain productivity in regions closer to the equator. In particular, environments experiencing warm night temperatures with high relative humidity are conducive to accelerated dark respiration rates as well as foliar diseases which can devastate wheat yields. Nonetheless, wheat is relatively well adapted to water deficit, being grown widely in semi-arid regions such as Central Asia, Australia, and throughout the Mediterranean region. Therefore, in regions which become progressively more arid, wheat may become more competitive than some of the currently grown crops. This could include maize which is especially sensitive to drought at flowering, leading to abortion of female reproductive structures in favour of pollen dispersal (Edmeades et al. 2000). There is also some evidence that increased $\mathrm{CO}_{2}$ will partially offset the effects of higher temperature and drought on wheat yields (and other $\mathrm{C} 3$ crops) through $\mathrm{CO}_{2}$ fertilization. These are benefits that are not realized in $\mathrm{C} 4$ crops such as maize or sorghum (Leakey et al. 2006).

Wheat in developing countries is expected to suffer most among major crops from rising temperatures (particularly night time temperatures) in low-latitude countries (Ortiz et al. 2008). Climate change may affect wheat production through heat stress, elevated carbon dioxide concentration and more variable precipitation resulting in altered crop development and a need to change farming practices (such as different sowing dates or more irrigation). Farmers are likely to adjust areas sown with wheat as land becomes more or less suitable due to changes in biotic constraints. Temperature elevation will likely have effects on grain-filling leading to smaller grain size and lower quality (Hodson and White 2009; Lobell and Burke 2010).

Indirect evidence of the potential to develop wheat genotypes that are adapted to climate change comes from the fact that breeding has already had considerable beneficial impacts in both marginal environments as well as temperate ones. For example, analysis of CIMMYT international nursery data shows clear and steady progress in the performance of both bread and durum wheat under drought stress (Ammar et al. 2008; Braun et al. 2010). In addition, analysis of germplasm released by CIMMYT for hot, irrigated environments shows significant progress, with many of the lines that perform well at the hottest sites also expressing good yield potential under more temperate conditions (Lillemo et al. 2005), an important consideration given typical year-to-year variation in temperature. Recent effort has focused on breeding for earlier maturing cultivars that escape terminal heat stress and encompass resistance to diseases associated with warm humid environments (Joshi et al. 2011) as well as the highly virulent stem rust strains of the Ug99 lineage.

Evidence of the adaptability of wheat to a broad range of environments is provided by both economic and physiological analyses. Between 1964 and 1979, around $25 \%$ of global wheat production increase came from improved production in marginal environments while between 1979 and 1998 impacts in drought and heat affected environments showed annual yield gains of 2-3\% per year (Lantican et al. 2003).

\section{Projected impacts of climate change}

About a decade ago, IFPRI estimated projected rates of yield growth at roughly $1.4-2.0 \%$ for developing countries through to 2020; this was double those of Eastern Europe and high income countries $(0.7-1.0 \%)$. Much has changed since then. Lobell and Field (2007) used statistical methods to quantify the ex-post impact of climatic variability on crop production in the 1980s and 1990s. Their results implied that increased warming between 1981 and 2002 has resulted in an average global wheat yield decrease of $88 \mathrm{~kg} / \mathrm{ha}$ although Hodson and White (2009) predicted that in certain regions, gains will result from the fertilization effects of carbon dioxide. Cool temperate wheat regions in the northern hemisphere may benefit. However, they conclude that gains in the aggregate mask other detrimental impacts for wheat producers in subtropical and tropical regions. For example, Ortiz et al. (2008) report that in a large proportion of areas of Eastern India that practice rice-wheat production, farmers already delay sowing of wheat to maximize profitability of the non-wheat cash crop; this means that the wheat crop is subject to sub-optimal, often hotter, temperatures.

More recently, Nelson et al. (2010) used process-based integrated models to quantity the potential biophysical and socioeconomic impact of climate change up to $2050 .{ }^{9}$ Based on their analysis, wheat yields in developing countries are

\footnotetext{
${ }^{9}$ The analysis by Nelson et al. (2010) involves an atmospheric $\mathrm{CO}_{2}$ concentration of $369 \mathrm{ppm}$ in 2050 . This value is substantially lower than most predictions on future greenhouse gas emissions.
} 
expected to decrease under climate change. Middle-income countries are predicted to experience a slightly greater decrease in rain-fed (5.3 to $5.6 \%$ ) compared to irrigated (4.8 to $5.3 \%$ ) wheat yields. On the other hand, low-income countries would experience a greater proportional decrease in irrigated (7.2 to $7.6 \%$ ) wheat yields compared to rain-fed systems (5.7 to $7.5 \%)$ ). For developed countries the simulated yield changes range from 0 to $0.1 \%$ increase for irrigated systems to losses of 7.4 to $8.9 \%$ for rain-fed systems.

The declining yield levels resulting from climate change will also affect projected production levels by $7-8 \%$ in both the developed regions and the developing regions. The findings from Nelson et al. (2010) imply that the negative effects of climate change on food productivity would decrease food availability and worsen human well-being; more specifically, by 2050 , the number of malnourished children would increase by 8.5 to $10.3 \%$ across all developing countries. The simulation results from Nelson et al. (2010) indicate relatively small changes in global land use due to climate change. A decrease of more than 1 million ha in cultivated crop area is predicted and most countries where decrease is likely to occur are in Asia, Europe, Northern America and Australia. The countries that will experience the highest increase in cultivated crop area are mainly in Africa and Latin America. The net effect of the scenarios on global land use is relatively small, although there is more dramatic variation in crop area changes by country. India and China are among those countries with a 9-10\% decline in crop area by 2050 relative to 2010, while Brazil and Nigeria have the greatest expansion; climate change reduces area in some cases and increases it to perfect mitigation in others. However, certain regions of the world (e.g. Khazakstan, Argentina, Angola and Mozambique) may still have potential for further expansion of wheat production into new regions, which will contribute to compensating any area losses from major producing regions in the tropics. These results are consistent with those from Mori et al. (2010) who predicted a substantial increase in cultivated land in Africa under global warming.

At the same time, demand for wheat in the developing world is projected to increase significantly. The rate of growth in demand for wheat is expected to move very close to growth in population but not as great as the demand for maize (because of biofuels and feed demand) and faster than the demand for rice (Dixon et al. 2009). One conclusion is clear from the projections of IFPRI and others: rates of yield growth of $1 \%$ will not be sufficient to meet global demand in the future (Fischer et al. 2009). There is a need to maintain genetic productivity gains of around $0.8-1 \%$ per year and add further gains from better agronomy and reduced crop losses through improved crop protection. This could lead up to $1.7 \%$ annual yield growth for wheat to meet growing demand for food security. Trade flows are a potentially important mechanism of adjustment to climate change. Wheat exports from developed countries are expected to decline from 2010 to 2050, regardless of model assumptions (Nelson et al. 2010). Despite rising global wheat trade, the US share of the world wheat market has eroded in the past two decades; the wheat area has contracted, domestic food use has dropped with changing consumer preferences, and in addition to the traditional global competitors (Canada, Argentina, Australia and the European Union), Ukraine and Russia have emerged as new competitors (USDA/ERS 2011).

\section{Future technology options}

The future technology options that are being developed by the International Maize and Wheat Improvement Centre (CIMMYT) and other international centres such as the International Centre of Agricultural Research for the Dry Areas (ICARDA) and national partners will aim to address the biotic and abiotic factors that limit the increase of sustainable productivity growth, especially under the threat of climate variability and change. This will include new varieties along with development of production systems that reduce risks and thereby enhance resilience and sustainability. This will include: conservation agriculture and agronomic practices that boost productivity, cut costs of production and improve resource-use efficiency.

\section{Breeding for improved yield and reduced risks}

In relation to biotic constraints, combating the most economically important rust diseases will continue to be the primary research priority in many regions. Genetic resistance, rather than fungicide use, has been, and will continue to be, the primary means of combating rust disease of wheat in developing countries. In developed countries, the demand by consumers for food produced without pesticide application will increase the need for disease resistant wheat varieties. Long-term international investments to develop and maintain a form of "durable" resistance based on multiple rather than single genes, ${ }^{10}$ has been spearheaded in the developing world by CIMMYT and its research partners. Enhancement of crop productivity is often measured in terms of positive yield gains and benefits from maintenance of productivity are estimated in terms of the yield losses that would have occurred in the absence of research investment. One particular difficulty in gauging benefit derives from genetic variation in pathogen populations and the potential

\footnotetext{
${ }^{10}$ Dubin and Brennan (2010) define two classes of resistance: racespecific resistance (also known as specific, major gene, or seedling resistance) and non-race-specific resistance (also known as partial, general, minor genetic nonspecific, adult plant, and slow rusting).
} 
for the emergence of new pathotypes that render ineffective forms of resistance that were previously effective (Marasas et al. 2004). Existing estimates of the economic impact of breeding for durable resistance have been summarized by Dubin and Brennan (2010). Direct estimates range from 0.9 to 2.5 US\$ billion, and indirect estimates from 0.7 to 2.9 US $\$$ billion, depending on the type of rust, the area affected and the time period studied. Dubin and Brennan (2010) report that, assuming a seven-year lag between investment and returns, the estimated total benefits of rust resistance are from US\$ 0.4 to 2.0 billion per year, generating an internal return on investment of 26 to $46 \%$ per year. Overall, they estimate that 60-120 million households and 117 million ha of wheat area had benefited from resistant varieties by 2006.

With regard to abiotic stresses, breeding work will remain focused on tackling the effects of drought and heat stress in relation to climate variability and change. One of the most effective strategies for adapting crops to heat and drought stress has been to select for changes in crop phenology so that critical growth stages do not coincide with stressful conditions, or the life cycle is completed before severe stress conditions occur (Ludlow and Muchow 1990). There is still considerable potential to modify patterns of crop development (Slafer et al. 2009). Another approach is to minimize the occurrence of stress through development of varieties with deeper rooting potential that enables water to be accessed from greater depths (Lopes and Reynolds 2010) and permits transpiration rates that better match evaporative demand, thereby permitting maximal carbon fixation with the added benefit of cooler plants (Reynolds et al. 2010). In environments where 'extra' water is not available to mitigate stress, other adaptive strategies include a range of leaf canopy traits such as epicuticular wax, pigment composition, leaf angle and rolling. These traits can influence radiation load and photosynthetic response, while increased transpiration efficiency permits available water to be used more effectively (Richards 2006; Reynolds et al. 2010).

Increased understanding of the genetic basis for adaptation to heat and drought stress (Pinto et al. 2010) will impact on breeding in two distinct ways; by increasing the efficiency of plant selection and by providing new opportunities for exploration of genetic resources (Reynolds et al. 2009). In this context, a significant advantage of wheat's hexaploid genome is that there is ample scope to broaden its adaptive potential by introducing genes from wild relatives through breeding (Trethowan and Mujeeb-Kazi 2008). A particularly ambitious approach to increasing the genetic potential of wheat is to elevate its radiation use efficiency (Parry et al. 2011). Among the strategies proposed are to genetically enhance the primary carbon fixing enzyme Rubisco and its regulation; if successful this would improve productivity of wheat in most agroecosytems including warmer, drier conditions.

In terms of approaches to adapting wheat to salinity or water-logging, genetic solutions are still mostly in the development stage (Mullan and Barrett-Lennard 2010). However, there are engineering solutions to water logging and salinity, stresses which already constrain productivity on hundreds of millions of hectares worldwide (Bhutta and Smedema 2007); with adequate large scale investment these would be highly effective in offsetting wide-scale productivity losses.

Climate change will be especially detrimental to wheat production in cropping systems where soils have been degraded to a point where they no longer provide sufficient buffering capacity (e.g. adequate water holding capacity) against drought and heat stress. These effects will be most severe if irrigation water is not available to compensate for decreased rainfall or to mitigate the effects of higher temperature. These problems cannot be addressed by improving genetic adaptation to heat or drought stress alone. They will also require agronomic interventions, including the adoption of resource conserving technologies such as those which underpin conservation agriculture: reduced tillage, residue management, and diverse but productive rotations (Hobbs and Govaerts 2010). As the effects of climate change intensify, policy decisions must recognize that benefits from investment in genetic technologies will not be fully realized unless crops are grown in well managed, stabilised soils that enable the genetic potential to be realised and buffer the crop against variable weather conditions.

\section{Conservation agriculture}

Long-term trials have demonstrated that modern wheat varieties do not achieve their potential without good agronomic management; wheat yields cannot be sustained with modern varieties alone. In recognition of this fact, conservation agriculture for raising productivity and resilience of farming systems is now a programme that complements the international wheat breeding effort to develop stress tolerant and high yielding varieties. Conservation agriculture follows principles to reduce tillage, retain crop residues, rotate crops, improve water use efficiency, and moderate damage from pests (Sayre and Govaerts 2009). The importance of irrigated wheat in developing countries has led to a focus on suitable technologies for those systems, such as reduced tillage on the Indo-Gangetic Plains of India and Pakistan (most recently assessed by Erenstein 2009), and bed planting in the Yaqui Valley of Mexico (initially, assessed by Aquino 1998).

Covering an estimated 14 million ha, the rice-wheat systems in the Indo-Gangetic Plains exemplified Asia's Green Revolution; today, they typify post-Green Revolution challenges related to resource degradation (Erenstein 2009). In the past decade, higher yields $(5-7 \%)$ and cost-savings (52 USD/ha, due to reduced tractor time and fuel) spurred rapid adoption of the zero-tillage drill, diffused by an active private 
sector and public-private partnerships catalyzed by the RiceWheat Consortium. To date, zero-tillage drilling of wheat is the most successful resource-conserving technology on the Indo-Gangetic Plains, particularly in the northwest (Erenstein 2009). Direct seeding of wheat after rice can save the farmer up to 30 days preparative labour, also avoiding heat stress induced by climate change (Sayre and Govaerts 2009). Benefits of investments by the Rice-Wheat Consortium in zero or reduced tillage have been estimated at a net present value of 94 million USD, a benefit-cost ratio of 39, and an internal rate of return of $57 \%$. However, many farmers have difficulty following the wider tenets of conservation agriculture, so that environmental benefits are yet to be fully realized (or measured). The vast, apparently homogeneous, irrigated tracts of land conceal the heterogeneity of practices and performance among smallholders. The social and environmental impacts of these changes remain largely uncharted given the variation that exists in livelihoods strategies, the availability of income and assets, and the ability of less endowed farmers to adopt changes (Erenstein 2009).

Water application methods in irrigated systems influence the water use efficiency of the wheat crop. Raised beds, initially tested and adopted from 1980 in the Yaqui Valley of Mexico, can create large savings in water use compared to irrigation on flat land. Wheat cultivars can be developed to exploit this effect (Trethowan et al. 2002). Plants are grown on raised beds that are divided by furrows for irrigation, with no tillage, and crop residues are chopped and left on the surface. Planting wheat on beds not only reduces water use, but also enables improved weed control, and leads to more efficient use of fertilizers, herbicides and seed. Beds can be re-used. Given the large contribution of inputs to crop production costs, these practices have resulted in significantly improved profits, particularly on clay soils (Aquino 1998).

\section{Technology targeting and adoption}

Modern wheat varieties were adopted more rapidly than any other technological innovation in the history of agriculture (Dalrymple 1986). In 1970, modern varieties of wheat covered only $5 \%$ of the wheat area in Sub-Saharan Africa and West Asia/North Africa; $42 \%$ in Asia (excluding China); and $11 \%$ in Latin America. This represented about $20 \%$ in the developing world. By 1990, modern varieties were sown on $70 \%$ of the wheat area in the developing world (Byerlee 1996), and by 1997, they represented $89 \%$ (Heisey et al. 2002). Lantican et al. (2005) estimated that nearly $90 \%$ of the developing world's wheat area was planted to modern varieties in 2002. This included semi-dwarf and improved, tall varieties of bread wheat and durum wheat. Adoption rates were highest for spring bread wheat, followed by spring durum, and winter and facultative wheat. ${ }^{11}$

Continued replacement of wheat varieties with new releases is important for sustaining increases in yield. Byerlee (1996) distinguished between the "revolutionary" adoption of modern varieties for the first time, and the "evolutionary" replacement of older improved varieties with newer releases. The latter is particularly significant, because it serves to maintain and protect yield advantages as biotic and abiotic pressures shift. By 1990, Byerlee and Traxler (1995) estimated that more than two-thirds of the benefits from research on spring bread wheat were generated in the postGreen Revolution areas where farmers replaced older with newer modern varieties, as compared to one-third in areas where farmers adopted modern varieties for the first time. Slow variety change, expressed by the area-weighted average age of varieties in farmers' fields, dampened wheat productivity in the Indian Punjab during the post-Green Revolution period, offsetting the positive gains of diversifying the genetic base in wheat breeding (Smale et al. 2008).

The already high adoption rate of improved cultivars also means that yield gains are more difficult to obtain than during the early days of the Green Revolution, when unimproved varieties were replaced with the high yielding Mexican semi-dwarfs, increasing yields three to four fold. For the coming decades, such spectacular gains are unlikely unless breeders are able to modify the plant (as pointed out in Section "Future technology options") so as to attain increased photosynthetic efficiency, reduced photorespiration and enhanced yield components.

The Green Revolution transformed wheat production in the benefiting areas, improved national and household food security and significantly reduced rural poverty (Fan and Hazell 2001; Evenson and Rosegrant 2003; Renkow and Byerlee 2010). However, several criticisms of the Green Revolution have endured because they continue to be important. One of the longstanding criticisms of wheat research concerns a historical bias toward well-watered, high-input farming systems as compared to wheat grown in more drought-prone and less-watered or low potential rainfed areas, which also suffer from limited market

\footnotetext{
${ }^{11}$ Classifying wheat is not as straightforward as it may seem. Farmers call the crop 'winter wheat' when it is sown before winter and 'spring wheat' when it is sown in the spring. Winter wheat carries vernalization genes, usually vrn 1 in combination with other vernalization genes. Vernalization is a temperature control mechanism in plants that ensures that plants do not enter the reproductive stages before winter. Exposure to prolonged cold winter temperature triggers flowering in the spring. Winter wheat will therefore not flower and produce grain if grown in areas where temperature is constantly high. Spring wheats require little or no vernalization prior to flowering. Facultative wheats, compared to true winter wheats, have in general less cold tolerance, a shorter but distinct period required for vernalization, start growth in spring earlier and flower earlier (Braun 1997).
} 
infrastructure and institutional development. The economic principles that research dollars are best invested where they have the highest benefit-cost ratio was qualified with concerns over equity. The argument that other investments, such as infrastructure, might more effectively reduce poverty in less favoured areas than agricultural research (Renkow 2000) was countered by empirical evidence that marginal returns to investment eventually decreased in higher potential areas and the poverty elasticity of investments in agricultural research was greater in less favoured areas of India and China (Fan and Hazell 2001). Some research demonstrated no investment bias toward favoured areas (Byerlee and Morris 1993) while other research identified a bias that was justifiable on both income and equity grounds (Renkow 1993). Dixon et al. (2006) pointed out that while the largest share of benefits derived from wheat breeding from 1960 to 1990 accrued to farmers in irrigated areas, roughly one half of the world's population that is living in poverty is located in the irrigated areas of South Asia.

More recently, based on their analysis of IMF data for 44 developing countries over the preceding two decades, Fan et al. (2008) found that: a) total agricultural expenditure had a significant effect on agricultural GDP and b) investment in agricultural research had a much larger output-promoting effect than other forms of public spending. In four distinct contexts (China, India, Thailand and Uganda) and in all cases, investment in agricultural research generated the largest or second largest impact on poverty reduction.

Whether or not there was a bias in research investment, there have clearly been disparities among regions with respect to adoption. However, some estimates suggest that growth rates in yield have been faster over some periods in drier or more heat-stressed environments than in irrigated and rain-fed production systems (Dixon et al. 2006; Heisey et al. 2002). Lantican et al. (2003) concluded that initial gains came from crossover of varieties from favourable environments, but targeted breeding efforts contributed significantly to more recent productivity growth in marginal environments, estimated to be twice that experienced in favourable environments from 1979. Yield variability in marginal environments also declined appreciably.

In a recent assessment of this literature and arguments on the impacts of the Green Revolution on poverty, Hazell (2010) concluded that the Green Revolution had powerful economywide and regional impacts through lower food prices for workers and demand for goods and services both inside and outside agriculture. Although benefits were predominately rural, poor urban dwellers also benefited. Initial studies showed that largeholder farmers benefited more than smallholders, but later studies disputed this point, and metaanalyses are inconclusive with respect to impacts on inequality. Asia's poorer regions benefited, if at all, through migration. Econometric analyses demonstrated that overall productivity growth had a significant negative effect on poverty rates in India and Asia, and that this effect was substantially greater in the longer run through the indirect effects of lower food prices and higher wages. Note, however, that while rural development indicators in some parts of the IndoGangetic plains of India compare well with middle income countries, large tracts remain "mired in poverty," such as the Eastern plains, where more than two-thirds of 500 million people live on less than 2 USD a day (Erenstein 2009).

While the Green Revolution "saved" large areas of forest and woodlands from conversion to agriculture through improving crop productivity, it also generated environmental problems (Hazell 2010). In their comprehensive analysis of wheat yield in Pakistan's Punjab, Byerlee and Siddiq (1994) found that the positive effects on wheat yields of the postGreen Revolution period were offset by environmental problems related to greater cropping intensity, poorer groundwater quality, low fertilizer use efficiency, and losses from weeds and disease. A more in-depth analysis conducted by Ali and Byerlee (2001) confirmed that soil and water degradation had lowered annual productivity growth by $0.22 \%$ in irrigated Punjab, suggesting that other factors such as pest complexes accounted for a further reduction of $0.31 \%$. There has also been growing evidence of saline and waterlogged soils in irrigated areas, falling water tables and a scarcity of fresh water (Byerlee 1996; Pingali and Rosegrant 2001; Shiferaw et al. 2008).

Dixon et al. (2006) provided a concise summary of some of the evidence regarding the determinants of adoption of improved wheat varieties, based largely on CIMMYT's research. First, they pointed out that countries in the developed world reach full adoption of a new variety several times more quickly than countries in the developing world. Slower diffusion among farmers in the developing regions reflects the fact that seed, other inputs, and product markets do not function as well, and price policies may not be as conducive, in developing as in developed countries. Thus, market performance and pricing schemes shape diffusion patterns for new wheat varieties.

Field-based studies have long focused on farmer characteristics as key determinants of adoption, as in the initial Green Revolution. Improved seed spread from farmer to farmer and was supported by solid government investments in market infrastructure. Over time, emphasis in adoption studies has shifted from the importance of farmer attitudes, risk perceptions, and formal education, to emphasis on farmer capital endowments. Access to land, labour, farm and household assets often explains creditworthiness, extension contacts, and capacity to bear risk. Access to social capital, and the extent and strength of participation in formal and informal groups and networks may substitute for or bolster the assets of individual farm households. These, in turn, figure heavily in information flows about new seed and 
practices, and how to use them. Differences in access to various types of capital also explain why new seed, a theoretically "scale-neutral" technology, is generally adopted first on larger farmers (see the much cited reviews by Feder et al. 1985; Feder and Umali 1993).

In addition to market and farmer characteristics, end-use and variety traits (such as fodder, bread-making quality) are often significant, especially in countries where wheat enjoys cultural centrality, as in North Africa, West Asia, and Ethiopia.

There are important differences between farmer decisions to invest in new varieties in comparison with new agronomic practices such as natural resource management which involves a change in labour requirements. There are also differences in the timing of costs and benefit streams as well as the composition of the benefits. Typically, improved agronomic practices have a much greater immediate impact on productivity when combined with the appropriate variety, and vice versa. However, most empirical research has demonstrated that when they are not themselves part of a particular promotion programme, farmers adopt new techniques in a stepwise fashion rather than as a package (Byerlee and de Polanco 1896; Shiferaw and Okello 2011). Usually, a greater share of the additional costs of improved agronomic practices involves the opportunity costs of labour, which varies over the cropping season and among farmers. A relatively larger proportion of the benefits of adopting such practices may emerge over time as soils and the cropping environment improve. Adoption of natural resource management practices often have positive impacts, not just for the farmer but also generates positive externalities for the community as a whole (Shiferaw et al. 2008). There are differences among techniques and among crop varieties which means that economic analyses must be conducted on a case-by-case basis.

\section{Conclusions}

Wheat is one of the key staple crops for global food security, providing more than $35 \%$ of the cereal calorie intake in the developing world, $74 \%$ in the developed world and $41 \%$ globally from direct consumption. It also contributes about one-fifth of the total calories and proteins of the total daily dietary intake. In addition to its use as food (70 \%), about $20 \%$ of the total demand is used as feed for livestock while $2-3 \%$ is used in industrial processing. Past research investments and productivity growth in wheat have played a central role in averting major famines in the developing world. The Green Revolution during the past half century dramatically transformed world wheat production, and consumers benefited from historically low food prices. Unfortunately, this success contributed to the complacency of policymakers and donors. Since the publication of the World Development Report in 2008, and the global food price crisis that ensued, policymakers have once again recognized that agricultural development is a "tried and true" strategy for poverty reduction. However, we also know that the transformation of the Green Revolution, like any agricultural change, was both incomplete and transient.

Another dramatic boost in wheat productivity on farms will be needed to meet the combined challenges of stagnating global yields, expanding consumer demand accompanied by higher, more volatile food prices, and the anticipated adverse impact of climate change. Yield gains will need to be achieved against a background of dwindling land and water resources. This can only be accomplished through investing in research that renews and fortifies the resistance of wheat to key pests and diseases, enhances its adaptation to warmer climates, and makes efficient use of water, fertilizer, labour, and fuel. As the incidence of drought increases and water available for irrigation becomes scarcer, wheat will be grown more often under rain-fed conditions. The world's primary regions for wheat production will shift, escalating risks to small-scale producers and exposing consumers in poor countries to extreme price fluctuations. Wheat farming systems in South Asia are projected to suffer most from heat stress and water scarcity due to climate change. The Indo-Gangetic Plains (IGPs) currently represents part of the favourable, high potential, irrigated, low rainfall mega-environment but as much as $51 \%$ of this area may be reclassified by 2050 as a heat-stressed, irrigated, short-season production mega-environment.

Deepening our understanding of vulnerabilities and promoting effective mechanisms for adaptation to and mitigation of climate change impacts also implies the need for new social, economic, and policy research for institutional innovation. Although the products of the Green Revolution gradually spread into more marginal zones for wheat production, and some areas have benefited from drought- and heat-tolerant varieties, adoption of new technologies in these areas has generally lagged behind that of more favoured areas. Areas that are marginal for agricultural production are also often neglected in terms of physical infrastructure, market, financial and social services. In other words, they are often lower on the policy agenda. This is a situation that will need to be rectified. Price increases impose great hardship on the poor, as the food price surge of 2008 made abundantly clear. To avoid recurring and increasingly intense food crises, wheat yields will have to increase at an annual rate of close to twice the current rate. As an added challenge, low commodity prices are not attractive to farmers; hence, both wheat production efficiency and productivity need to increase, to balance the needs of consumers and farmers.

The future of global food security in wheat depends on new varieties and management practices to meet the demand from differentiated value chains, address the projected negative impacts of climate change, and reverse the stagnating productivity trends in the post-Green Revolution areas. While several rainfed areas also benefited from semi-dwarf varieties, technology 
adoption in the rain-fed and riskier growing regions has generally been slow and has lagged behind other areas. Better institutional innovations and policy options are needed for replacing outdated varieties with modern cultivars and stimulating farmer investments in sustainable crop, soil and water management. Achieving the productivity increases needed to ensure regional and global food security will require more than a repeat performance of the Green Revolution, because conditions have changed since the 1960s. The diffusion of new stress-tolerant and high-yielding varieties particularly needs to go hand in hand with sustainable crop and natural resource management practices to prevent worsening water scarcity and soil degradation, which keep farmers from realizing the benefits of new technologies and thus reduce incentives to adopt them. The enduring lessons from adaptation of integrated innovations for cereal systems in South Asia and other regions will provide useful insights for sustainable productivity growth in wheat for the future.

The demand for wheat in the developing world is projected to increase significantly in the coming decades. Meeting this demand will require concerted efforts in research and innovation to develop and deploy solutions to existing and emerging challenges. Substantive investment will be required to realize such a strategy, through strategic alliances with institutions worldwide that share a common vision. The enormity of the challenges calls for an intensified and coordinated effort of both public and private partners in the developing and developed world. Such an effort is in line with other calls for coordinated international action on global food security threats, such as the Millennium Development Goal initiatives and the L'Aquila Joint Statement by leaders of the world's largest economies in July 2009. As a response to the growing needs to enhance wheat productivity, the collaborative global research program on wheat was recently prepared by CIMMYT and ICARDA. This was done in consultation with national and international agricultural research institutions, universities as well as private sector, non-governmental and farmer organisations. The programme describes a strategy for wheat improvement to contribute to improved food security and the livelihoods of the resource-poor in the developing world. The financial investments required are small relative to total global development assistance or the expected global costs of addressing climate change; but potential returns are high. A successful programme will make a significant contribution to achieving global food security and enable millions of pre-commercial farmers and smallholder producers to become market participants.

Open Access This article is distributed under the terms of the Creative Commons Attribution License which permits any use, distribution, and reproduction in any medium, provided the original author(s) and the source are credited.

\section{References}

Ali, M., \& Byerlee, D. (2001). Productivity growth and resource degradation in Pakistan's Punjab. In E. M. Bridges et al. (Eds.), Response to land degradation (pp. 186-199). Enfield: Science Publishers.

Ali, M., \& Vocke, G. (2002). How wheat costs vary. Special Article. Wheat yearbook WHS-2002 (pp. 14-20). Washington: US Department of Agriculture, Economic Research Service.

Ammar, K., Lage, J., Villegas, D., Crossa, J., Hernandez, H., \& Alvarado, G. (2008). Association among durum wheat international testing sites and trends in yield progress over the last twenty-two years. In M. P. Reynolds, J. Pietragalla, \& H.-J. Braun (Eds.), International symposium on wheat yield potential: Challenges to international wheat breeding (pp. 108-119). Mexico: CIMMYT.

Aquino, P. (1998). The adoption of bed planting of wheat in the Yaqui Valley, Sonora, Mexico. Wheat special report no. 17A. Mexico: CIMMYT.

Aquino, P., \& Carrión, F. (2009). Selected wheat statistics. In J. Dixon, H. J. Braun, P. Kosina, \& J. Crouch (Eds.), Wheat facts and futures 2009. Mexico: International Maize and Wheat Improvement Center (CIMMYT).

Bagci, S. A., Ekiz, H., Yilmaz, A., \& Cakmak, I. (2007). Effects of zinc deficiency and drought on grain yield of field-grown wheat cultivars in Central Anatolia. Journal of Agronomy and Crop Science, 193, 198-206.

Barnabas, B., Jager, K., \& Feher, A. (2008). The effect of drought and heat stress on reproductive processes in cereals. Plant, Cell \& Environment, 31, 11-38.

Bates, B. C., Kundzewicz, Z. W., Wu, S., \& Palutikof, J. P. (2008). Climate change and water. Technical paper of the intergovernmental panel on climate change. Geneva: IPCC Secretariat. $200 \mathrm{pp}$

Bhutta, M. N., \& Smedema, L. K. (2007). One hundred years of waterlogging and salinity control in the Indus valley, Pakistan: a historical review. Irrigation and Drainage, 56, S81-S90.

Braun, H.-J. (1997). Winter hardiness of bread wheats derived from spring x winter crosses. Acta Agronomica Hungarica, 45(3), 317-327.

Braun, H. J., Atlin, G., \& Payne, T. (2010). Multi-location testing as a tool to identify plant response to global climate change. In M. P. Reynolds (Ed.), Climate change and crop production. Wallingford: CABI.

Burke, J. J., Mahan, J. R., \& Hatfield, J. L. (1988). Crop-specific thermal kinetic windows in relation to wheat and cotton biomass production. Agronomy Journal, 80, 553-556.

Byerlee, D. (1992). Technical change, productivity, and sustainability in irrigated cropping systems of South Asia: emerging issues in the postGreen Revolution era. Journal of International Development, 4(5), 477-496.

Byerlee, D. (1996). Modern varieties, productivity, and sustainability: recent experience and emerging challenges. World Development, 24(4), 697-718.

Byerlee, D., \& de Polanco, E.H. (1896). Farmers' stepwise adoption of technological packages: evidence from the Mexican Altiplano. American Journal of Agricultural Economics, 519-527

Byerlee, D., \& Morris, M. (1993). Have we underinvested in research for marginal environments? Food Policy, 18, 381-393.

Byerlee, D., \& Siddiq, A. (1994). Has the Green Revolution been sustained? The quantitative impact of seed-fertilizer revolution in Pakistan revisited. World Development, 22(9), 1345-1361.

Byerlee, D., \& Traxler, G. (1995). National and international wheat improvement research in the post-Green Revolution period: evolution and impacts. American Journal of Agricultural Economics, 77(2), 268-278.

CIMMYT (2011) WHEAT: A global alliance for improving food security for resource-poor in developing world. Strategic Initiative, 5, 118- 
127. http://wheat.org/resources/crp-wheat-proposal, submitted by CIMMYT and ICARDA, accessed 15 March 2013.

Cordell, D., Drangert, J. O., \& White, S. (2009). The story of phosphorus: global food security and food for thought. Global Environmental Change, 19, 292-305.

Dalrymple, D. G. (1986). Development and spreading of high yielding varieties in developing countries. Washington: US Agency for International Development.

Datt, G., \& Ravallion, M. (1998). Farm productivity and rural poverty in India. Journal of Development Studies, 34, 62-85.

Deininger, C., Byerlee, B., Lindsay, J., Norton, A., Selod, H., \& Stickler, M. (2010). Rising global interests in farmland: Can it yield sustainable and equitable benefits. Washington: Agricultural and Rural Development Dept, World Bank.

Dixon, J., Nalley, L., Kosina, P., La Rovere, R., Hellin, J., \& Aquino, P. (2006). Adoption and economic impact of improved wheat varieties in the developing world. Journal of Agricultural Science, $144,489-502$.

Dixon, J., Braun, H. J., \& Crouch, J. (2009). Transitioning wheat research to meet the future demands of the developing world. In J. Dixon, H. J. Braun, P. Kosina, \& J. Crouch (Eds.), Wheat facts and futures 2009. Mexico: International Maize and Wheat Improvement Center (CIMMYT).

Dubin, H. J., \& Brennan, J. P. (2010). Combating stem and leaf rust of wheat: Historical perspective, impacts, and lessons learned. In D. J. Spielman \& R. Pandya-Lorch (Eds.), Proven successes in agricultural development: A technical compendium to millions fed. Washington: International Food Policy Research Institute.

Duveiller, E., \& Sharma, R. C. (2009). Genetic improvement and crop management strategies to minimize yield losses in warm non-traditional wheat growing areas due to spot blotch pathogen Cochliobolus sativus. Journal of Phytopathology, 157, 521-534.

Duveiller, E., Singh, R. P., \& Nicol, J. (2007). Challenges to maintaining wheat productivity: pests, diseases and potential epidemics. Euphytica, 157, 417-430.

Duveiller, E., Hodson, D., \& Tiedemann, V. (2010). Wheat blast caused by Maganaporthe oryzae: a reality and new challenge for wheat research. In N. I. Dzyubenko (Ed.), The 8th International Wheat Conference, abstracts, 1-4 June 2010 (pp. 247-248). Russia: St Petersburg.

Edmeades, G. O., Bolaños, J., Elings, A., Ribaut, J. M., Bänziger, M., $\&$ Westgate, M. E. (2000). The role and regulation of the anthesis-silking interval in maize. In M. E. Westgate \& K. J. Boote (Eds.), Physiology and modeling kernel set in maize, CSSA special publication no. 29 (pp. 43-73). Madison: CSSA.

Erenstein, O. (2009). Zero tillage in the rice-wheat systems of the IndoGangetic plains: A review of impacts and sustainability implications. IFPRI Discussion Paper 00916. Washington: International Food Policy Research Institute.

Evenson, R. E., \& Rosegrant, M.W. (2003). The economic consequences of crop genetic improvement programmes. In R. Evenson \& D. Gollin (Eds.), Crop variety improvement and its effect on productivity: The impact of international agricultural research. CABI Publishing.

Fan, S., \& Hazell, P. (2001). Returns to public investments in the lessfavored areas of India and China. American Journal of Agricultural Economics, 83(5), 1217-1222.

Fan, S., Yu, B., \& Saurkar, A. (2008). Public spending in developing countries: Trends, determination and impacts. In S. Fan (Ed.), Public expenditures, growth and poverty: Lessons from developing countries. Baltimore: International Food Policy Research Institute and Johns Hopkins University Press.

Feder, G., \& Umali, D. (1993). The adoption of agricultural innovations a review. Technological Forecasting and Social Change, 43 (3-4), 215-3239.
Feder, G., Just, R., \& Zilberman, D. (1985). Adoption of agricultural innovations in developing countries: a survey. Economic Development and Cultural Change, 33, 255-297.

Fischer, R. A., Byerlee, D., Edmeaes, G.O. (2009). Can technology deliver on the yield challenge to 2050? Paper prepared for the Expert Meeting on How to Feed the World in 2050, Rome 24-26 June, Food and Agriculture Organization of the United Nations.

Gollin, D. (2006). Impacts of international research on intertemporal yield stability in wheat and maize: An economic assessment. Mexico: CIMMYT.

Hazell, P. B. R. (2010). The Asian green revolution. In D. J. Spielman \& R. Pandya-Lorch (Eds.), Proven successes in agricultural development: A technical compendium to millions fed. Washington: International Food Policy Research Institute.

Heisey, P. W., \& Norton, G. (2007). Fertilizers and other farm chemicals. In R. Evenson \& P. Pingali (Eds.), Handbook of Agricultural Economics, vol 3, Elsevier.

Heisey, P. W., Lantican, M. A., \& Dubin, H. J. (2002). Impacts of international wheat breeding research in developing countries, 1966-97. CIMMYT: Mexico.

Hibbert, C. (1980). The days of the french revolution. New York: William Morrow and Co. Institute.

Hobbs, P., \& Govaerts, B. (2010). How conservation agriculture can contribute to buffering climate change. In M. P. Reynolds (Ed.), Climate change and crop production. London: CABI.

Hodson, D., \& White, J. (2009). Climate change: What Future Wheat? In J. Dixon, H. J. Braun, P. Kosina, \& J. Crouch (Eds.), Wheat facts and futures 2009. Mexico: International Maize and Wheat Improvement Center (CIMMYT).

Hsiao, T. C. (2003). Plant responses to water stress. Annual Review of Plant Physiology, 24, 519-570.

Joshi, A. K., Azab, M., Mosaad, M., Moselhy, M., Osmanzai, M., Gelalcha, S., et al. (2011). Delivering rust resistant wheat to farmers: a step towards increased food security. Euphytica, 179, $187-196$.

Lantican, M. A., Pingali, P. L., \& Rajaram, S. (2003). Is research on marginal lands catching up? The case of unfavorable wheat growing environments. Agricultural Economics, 29, 353-361.

Lantican, M. A., Dubin, H. J., \& Morris, M. L. (2005). Impacts of international wheat breeding research in the developing world, 1988-2002. Mexico: CIMMYT.

Leakey, A. D. B., Uribelarreã, M., Ainsworth, E. A., Naidu, S. L., Rogers, A., Ort, D. R., et al. (2006). Photosynthesis, productivity, and yield of maize are not affected by open-air elevation of $\mathrm{CO}_{2}$ concentration in the absence of drought. Plant Physiology, 140, 779-790.

Legrève, A., \& Duveiller, E. (2010). Preventing potential disease and pest epidemics under a changing climate. In M. P. Reynolds (Ed.), Climate change and crop production (pp. 50-70). Wallingford: CABI.

Lillemo, M., Ginkel, M. V., Trethowan, R. M., Hernandez, E., \& Crossa, J. (2005). Differential adaptation of CIMMYT bread wheat to global high temperature environments. Crop Science, $45,2443-2453$.

Lobell, D., \& Burke, M. (2010). Economic impacts of climate change in agriculture. In M. P. Reynolds (Ed.), Climate change and crop production. Wallingford: CABI.

Lobell, D. B., \& Field, C. B. (2007). Global scale climate-crop yield relationships and the impacts of recent warming. Environmental Research Letters, 2, 1-7. doi:10.1088/1748-9326/2/1/014002.

Lobell, D. B., Schlenker, W., \& Costa-Roberts, J. (2011). Climate trends and global crop production since 1980. Science, 333, 616.

Lopes, M. S., \& Reynolds, M. P. (2010). Partitioning of assimilates to deeper roots is associated with cooler canopies and increased yield under drought in wheat. Functional Plant Biology, 37(2), $147-156$. 
Ludlow, M. M., \& Muchow, R. C. (1990). A critical evaluation of traits for improving crop yields in water-limited environments. Advances in Agronomy, 43, 107-153.

Marasas, C., Smale, M., \& Singh, R. P. (2004). The economic impact in developing countries of leaf rust resistance breeding in CIMMYTrelated spring bread wheat. Economics program paper 04-01. Mexico: CIMMYT.

Meng, Loyns, E. A., \& Peña, R. J. (2009). Wheat quality in the developing world: Trends and opportunities. In J. Dixon, H. J. Braun, P. Kosina, \& J. Crouch (Eds.), Wheat facts and futures 2009. Mexico: International Maize and Wheat Improvement Center (CIMMYT).

Mohammed, A. R., \& Tarpley, L. (2009). Impact of high night time temperature on respiration, membrane stability, antioxidant capacity, and yield of rice plants. Crop Science, 49, 313-322.

Mori, S., Kato, M., \& Ido, T. (2010). GISELA - GIS-based evaluation of land use and agriculture market analysis under global warming. Applied Energy, 87, 236-242.

Mullan, D. J., \& Barrett-Lennard, E. G. (2010). Breeding crops for tolerance to salinity, waterlogging and inundation. In M. P. Reynolds (Ed.), Climate change and crop production. London: CABI.

Nelson, G. C., Rosegrant, M. W., Palazzo, A., Gray, I., Ingersoll, C., Robertson, R., et al. (2010). Food security, farming, and climate change to 2050: Scenarios, results, policy options. Washington: IFPRI.

Oerke, E. C. (2006). Crop losses to pests. Journal of Agricultural Science, 144, 31-43.

Oerke, E. C., \& Dehne, H. W. (2004). Safeguarding production-losses in major crops and the role of crop protection. Crop Protection, 23, 275-285.

Ortiz, R., Sayre, K. D., Govaerts, B., Gupta, R., Subbarao, G. V., Ban, T., et al. (2008). Climate change: can wheat beat the heat? Agriculture, Ecosystems \& Environment, 126, 46-58.

Pal, S., \& Byerlee, D. (2005). India: the funding and organization of agricultural $\mathrm{R} \& \mathrm{D}$ - evolution and emerging policy issues. In P. Pardey, J. Alston, \& R. Piggott (Eds.), Agricultural R\&D in the developing world. Washington: International Food Policy Research Institute.

Parry, M. A. J., Reynolds, M. P., Salvucci, M. E., Raines, C., Andralojc, P. J., Zhu, X. G., et al. (2011). Raising yield potential of wheat. II. Increasing photosynthetic capacity and efficiency. Journal of Experimental Botany, 62(2), 453-467.

Payne, T. S. (2002). Harvest and storage management of wheat. In B. C. Curtis, S. Rajaram, \& H. G. Macpherson (Eds.), Bread wheat: Improvement and production. FAO plant production and protection series no. 30. Rome: Food and Agriculture Organization of the United Nations.

Pingali, P. (2007). Westernization of Asian diets and the transformation of food systems: implications for research and policy. Food Policy, 32, 281-298

Pingali, P. L., \& Rosegrant, M. (2001). Intensive food systems in Asia: Can the degradation problems be reversed? In D. R. Lee \& C. B. Barrett (Eds.), Tradeoffs or synergies? Agricultural intensification. Economic development and environment (pp. 383-397). Wallingford: CABI Publishing.

Pinto, R. S., Reynolds, M. P., Mathews, K. L., McIntyre, C. L., Olivares-Villegas, J. J., \& Chapman, S. C. (2010). Heat and drought adaptive QTL in a wheat population designed to minimize confounding agronomic effects. Theoretical and Applied Genetics, 121, 1001-1021.

Rejesus, R. M., Heisey, P. W., \& Smale, M. (1999). Sources of productivity growth in wheat: A review of recent performance and medium- to long-term prospects. Economics working paper 9905. Mexico: International Maize and Wheat Improvement Center.

Renkow, M. (1993). Differential technology adoption and income distribution in Pakistan: implications for research resource allocation. American Journal of Agricultural Economics, 74, 33-43.
Renkow, M. (2000). Poverty, productivity, and production environment: a review of the evidence. Food Policy, 25, 463-478.

Renkow, M., \& Byerlee, D. (2010). The impacts of CGIAR research: a review of recent evidence. Food Policy, 35, P 391-P 402.

Reynolds, M. P., Manes, Y., Izanloo, A., \& Langridge, P. (2009). Phenotyping for physiological breeding and gene discovery in wheat. Annals of Applied Biology, 155, 309-320.

Reynolds, M. P., Hays, D., \& Chapman, S. (2010). Breeding for adaptation to heat and drought stress. In M. P. Reynolds (Ed.), Climate change and crop production. London: CABI.

Richards, R. A. (2006). Physiological traits used in the breeding of new cultivars for water-scarce environments. Agricultural Water Management, 80, 197-211.

Sayre, K. D., \& Govaerts, B. (2009). Conservation agriculture for sustainable wheat production. In J. Dixon, H. J. Braun, P. Kosina, \& J. Crouch (Eds.), Wheat facts and futures 2009. Mexico: International Maize and Wheat Improvement Center (CIMMYT).

Semenov, M. A., \& Shewry, P. R. (2011). Modelling predicts that heat stress, not drought, will increase vulnerability of wheat in Europe. Scientific Reporter, 1, 1-6.

Shiferaw, B., \& Okello, J. (2011). Stimulating Smallholder Investments in Sustainable Land Management: Overcoming Market, Policy and Institutional Challenges. In R. Bluffstone \& Kohlin G. Determinants of Investments in Sustainable Agriculture in East Africa. Resources for the Future Press.

Shiferaw, B., Reddy, V. R., \& Wani, S. (2008). Watershed externalities, shifting cropping patterns and groundwater depletion in Indian semi-arid villages: the effect of alternative water pricing policies. Ecological Economics, 67(2), 327-340.

Shiferaw, B., Prasanna, B. M., Hellin, J., \& Bänziger, M. (2011). Crops that feed the world. Past successes and future challenges to the role played by maize in global food security. Food Security, 3(3), 307-327.

Singh, A. J., \& Byerlee, D. (1990). Relative variability in wheat yields across countries and over time. Journal of Agricultural Economics, 41(1), 21-32.

Singh, A., Singh, S., \& Rao, S. N. (2003). Integrated pest management in India. In K. Maredia, D. Dakouo \& D. Mota-Sanchez (Eds.) Integrated pest management in the global arena. Karim Maredia, D. Dakouo, D. Mota-Sanchez. CABI Publishing.

Singh, R. P., Hodson, D. P., Huerta-Espino, J., Jin, Y., Bhavani, S., Njau, P., et al. (2011). The emergence of Ug99 races of the stem rust fungus is a threat to world wheat production. Annual Review of Phytopathology, 49, 465-481.

Slafer, G. A., Kantolic, A. G., Appendino, M. L., Miralles, D. J., \& Savin, R. (2009). Crop development: genetic control, environmental modulation and relevance for genetic improvement of crop yield. In V. O. Sadras \& D. F. Calderini (Eds.), Crop physiology: Applications for genetic improvement and agronomy (pp. 277308). The Netherlands: Elsevier.

Smale, M., Singh, J., Di Falco, S., \& Zambrano, P. (2008). Wheat breeding, productivity and slow variety change: evidence from the Punjab of India after the Green Revolution. The Australian Journal of Agricultural and Resource Economics, 52, 419-432.

Smith, B. D. (1998). The emergence of agriculture. New York: Scientific American Library.

Trego, R. (2011). The functioning of the Egyptian food-subsidy system during food price shocks. Development in Practice, 21(4-5), 666-678.

Trethowan, R. M., \& Mujeeb-Kazi, A. (2008). Novel germplasm resources for improving environmental stress tolerance of hexaploid wheat. Crop Science, 48, 1255-1265.

Trethowan, R. M., Ginkel, M. V., \& Sanjaya, R. (2002). Progress in breeding wheat for yield and adaptation in global drought affected environments. Crop Science, 42, 1441-1446.

Tripp, R. (2006). Self-sufficient agriculture: Labour and knowledge in small-scale farming. London: Earthscan. 
US Department of Agriculture, Economic Research Service (USDA/ ERS), Wheat Briefing Room (2011). http://www.ers.usda.gov/ Briefing/Wheat/. Accessed on June 20, 2011.

Wardlaw, I. F., Dawson, I. A., Munibi, P., \& Fewster, R. (1989). The tolerance of wheat to high temperatures during reproductive growth. Survey procedures and general response patterns. Australian Journal of Agricultural Research, 40, 1-13.

Wassmann, R., Jagadish, S. V. K., Heuer, S., Ismail, A., Redona, E., Serraj, R., et al. (2009). Climate change affecting rice production. The physiological and agronomic basis for possible adaptation strategies. Advances in Agronomy, 101, 59-122.

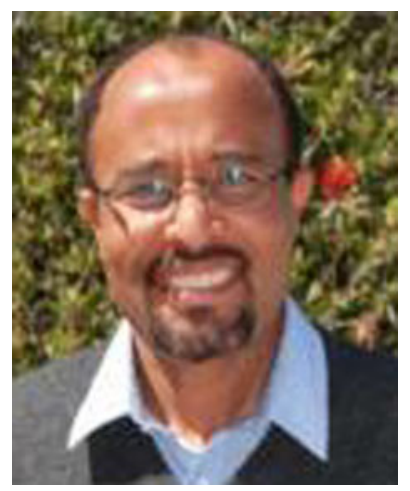

Bekele Shiferaw is an Agricultural and Development Economist with the Socio-Economics Program at the International Maize and Wheat Improvement Center (CIMMYT), based in Nairobi, Kenya. His research interests span analysis of institutions and policies for agricultural development and change; linking knowledge with policy and action; determinants of technology adoption; measurement of development and environmental impacts of policy interventions; analysis of market relations and commodity value chains; policy and institutional innovations for remedying market failures; and strategies for enhancing adaptation to and mitigation of climate change impacts on agriculture. $\mathrm{He}$ has extensive experience on agricultural transformation, sustainable development and drivers of change in the developing regions. He has published over 50 papers in peer-reviewed international journals and books. He received his Ph.D degree in Development and Resource Economics from the Department of Economics and Resource Management, University of Life Sciences (UMB), Norway.

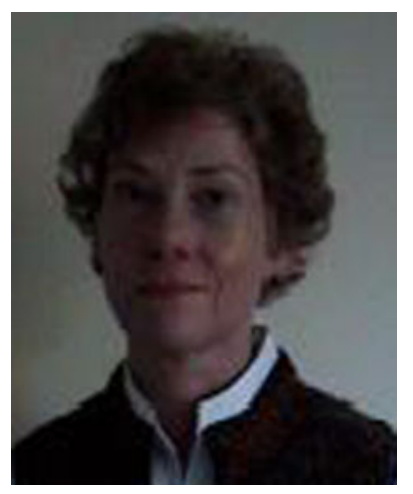

Melinda Smale joined the Food Security Group in the Department of Agricultural, Food and Resource Economics at Michigan State University in 2011. She worked for a number of years as a Senior Research Fellow at the International Food Policy Research Institute (IFPRI), and as an Economist at Bioversity International and the International Maize and Wheat Improvement Center (CIMMYT), based in Mexico and Malawi. During the 1980s, Melinda worked in Pakistan, Somalia, Mauritania and Niger on shorter-term assignments for a number of organizations. She is an Honorary Fellow with Bioversity International, serving on the Advisory Committee of the Collaborative
Crops Research Program of the McKnight Foundation, and on the editorial committees of two journals. She has awards for outstanding journal articles from the Agricultural and Applied Economics Association and the Crop Science Society of America, and has published over 67 articles in peer-reviewed journals, 5 edited books, and 25 book chapters. She received her $\mathrm{PhD}$ in Agricultural Economics from the University of Maryland.

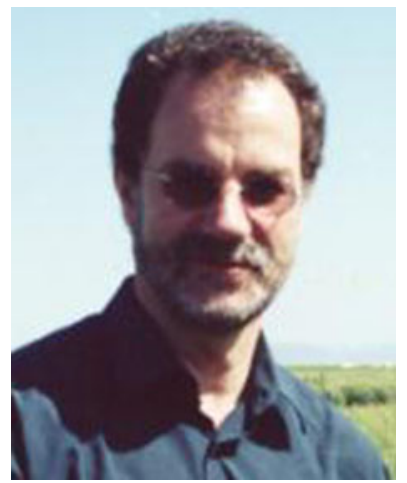

Hans-Joachim Braun a native of Germany with background in wheat breeding and based in Mexico, is since 2004 Director of CIMMYT's Global Wheat Program, which develops and distributes wheat germplasm to more than 250 cooperates in around 100 countries. Before he lived for 20 years in Turkey, leading the TURKEY CIMMYT ICARDA International Winter Wheat Improvement Program. He contributed to the development of more than 40 winter wheat varieties released mainly in West and Central Asia which are grown on more than $1.5 \mathrm{mlln}$ ha and he was instrumental in recognizing $\mathrm{Zn}$ deficiency and soil borne diseases as major constraints for winter wheat production in the dryland areas of West Asia. He has published more than 50 peer-reviewed articles and book chapters. He received his $\mathrm{PhD}$ from the University of Hohenheim, Germany.

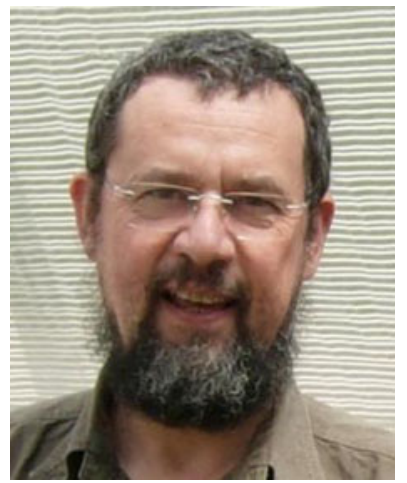

Etienne Duveiller is a CIMMYT plant pathologist with more than 30 year experience in international agriculture and development projects. After working in capacity building in Bolivia, and in Burundi on rice diseases, he joined CIMMYT Wheat Program in 1987 and specialized in wheat disease resistance and integrated crop management. Dr. Duveiller spent most of his career in CIMMYT Mexico, and as Regional Wheat Pathologist based in Nepal. He is currently Director of Research of the Borlaug Institute for South Asia and Associate Director of the Global Wheat Program. Dr. Duveiller received if $\mathrm{PhD}$ from University of Louvain (UCL) in Belgium. 


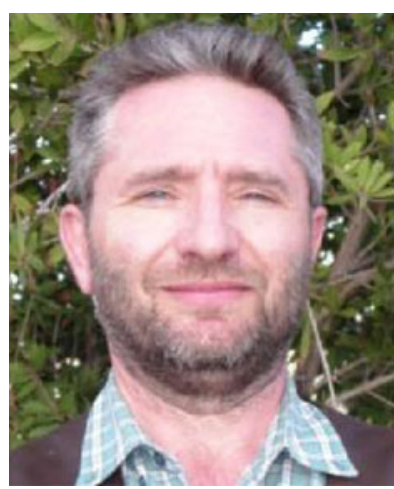

Matthew Reynolds works at the International Maize and Wheat Improvement Centre where his professional goals are to develop and transfer technologies to increase productivity of wheat cropping systems worldwide with a special focus on developing countries. His impacts include a new generation of advanced wheat lines based on physiological breeding approaches, increased understanding of adaptation of wheat to abiotic stress, and over 100 publications in peer-reviewed journal articles. He established the international Wheat Yield Consortium and recently edited a book entitled Crop Adaptation to Climate Change. He holds honorary positions at Nottingham University, Oklahoma State University, and the Australian Centre for Plant Functional

Genomics, and serves on the advisory boards of BREEDWHEAT (France) and TRITICAE-CAP (USA).

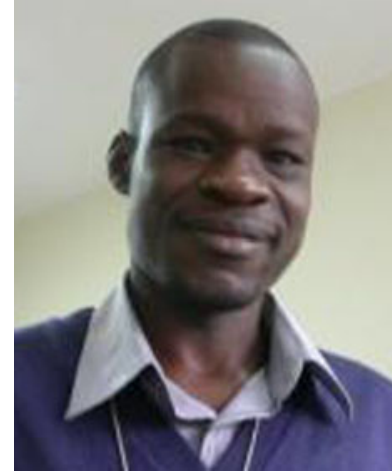

Tropics (ICRISAT).
Geoffrey Muricho is an Associate Researcher with the International Maize and Wheat Improvement Center (CIMMYT) in Nairobi. He has several years of experience on analysis of smallholder production, institutions and policies in Eastern and Southern Africa. He has extensively travelled in the region in conducting various farm, community and market level studies on a range of food crops. Before joining CIMMYT he worked with the International Crops Research Institute for the Semi Arid 